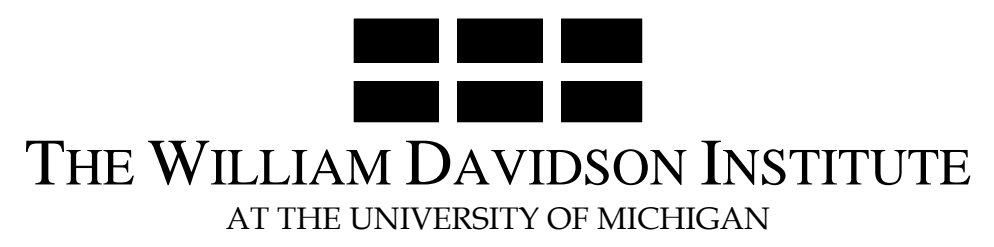

AT THE UNIVERSITY OF MICHIGAN

\title{
MODELING INSTITUTIONS, START-UPS AND Productivity during Transition
}

\author{
By: Zuzana Brixiová and Balázs Égert
}

William Davidson Institute Working Paper Number 975

February 2010 


\title{
Modeling Institutions, StART-UPs ANd Productivity DURING Transition ${ }^{1}$
}

\author{
Zuzana Brixiová * and Balázs Égert ** \\ * African Development Bank, Development Research Department \\ ** Organization for Economic Cooperation and Development, Economics Department
}

February 2010

The transition paths from plan to market have varied markedly across countries. Central and Eastern European and the Baltic countries, which opted for a fast and profound transformation of their institutions including business climates, rapidly narrowed the productivity gap with advanced economies. In contrast, in countries of the Commonwealth of Independent States, which embarked on reforms later and contented with less depth, the productivity gap remains substantial. While the literature has focused mainly on empirical studies, this paper develops a dynamic search model of the firm start-ups that is consistent with the above trends. The model shows that an enabling institutional set up stimulates start-ups of highly productive firms at an earlier stage of transition, underscoring the importance of reforms. The role of the state sector as an employer during transition rises in countries where reforming institutions is particularly costly.

Key words: Start-ups, dynamic search model, business climate, productivity, transition

JEL classification: O43, O14, O57, C61, C63

\footnotetext{
${ }^{1}$ We are especially thankful to Egbert Jongen and Dale Mortensen for helpful comments. We also thank Jan Babecky, Jens Hoj, Wenli Li, Mark Schaffer, Arnim Schwidrowski, and Alf Vanags for their insights at various stages of this paper. Earlier versions were presented at the 2008 International Conference on Contemporary Labor Economics (Xiamen), the $65^{\text {th }}$ Congress of the International Institute of Public Finance on Public Finance and Development (Cape Town), the UNU-WIDER Conference on Reflections on Twenty Years since the Fall of the Berlin Wall (Helsinki), and the 2010 ACES/ASSA meetings (Atlanta). The views expressed are those of the authors and do not necessarily reflect those of the African Development Bank or the Organization for Economic Cooperation and Development. E-mail addresses: z.brixiova@afdb.org and balazs.egert@oecd.org.
} 
The transition from plan to market has been extensively dealt with empirically at the firm level, including the impact of institutions, especially the business climate, and new firms on economywide productivity, output, and employment growth (Fagio and Koning, 2003; Berkowitz and DeJong, 2005, Klapper, Lavean and Rajan, 2005; De Loecker and Konings, 2006). On the aggregate level, the labor relocation from the less productive state to the more productive private sector was a key issue in the theoretical literature, pioneered by Aghion and Blanchard (1994), and further developed by Atkinson and Kehoe (1996) and Brixiova and Kiyotaki (1997), Castanheira and Roland (2000) and others. The experience of the past two decades has shown that a successful transition hinges on the dynamic private sector, and especially new firms, to drive the productivity and employment growth. At the same time, the global financial and economic crisis demonstrated usefulness of well-targeted government interventions, including job creation.

This paper develops a theoretical framework that examines the role of institutions, with a focus on the business climate, firm start-ups and exits as well as the observed productivity and employment paths during transition. It also discusses the role of the state sector as an employer when reforming institutions is particularly costly. Specifically, the paper presents a dynamic search model that shows how an enabling institutional set up stimulates start-ups of highly productive private firms, leading to a fast recovery of productivity and increased share of good (highly productive and well-paid) jobs during the transition. The model explains some of the diverging economic outcomes between the Central and Eastern European and Baltic (CEEB) and the Commonwealth of Independent States (CIS) economies. The CEEB countries embarked swiftly on economic reforms including the transformation of the institutional infrastructure in general and the business climate in particular. In contrast, the CIS countries were slower in implementing reforms and still have a long way to go to achieve business climate quality that has been already established in the CEEB economies (Mitra, Muravyev and Schafer, 2009).

Labor relocation during transition was accompanied by a debate on the role of the state sector in the economy, including as an employer (Roland, 2000; Tichit, 2006). The issue was viewed as important because the social costs of transition, in particular high and persistent unemployment, could have slowed the transition and possibly bring it to a halt. And in fact, it is the concern about the social cost of adjustment that prevents some countries, such as Belarus, to adopt more decisive market reforms. With declining unemployment and emerging labor shortages in the CEEB countries during the boom of 2000-07, the debate seemed over. The private sector was seen as the best way to achieve growth with employment and social stability, and the selfcorrecting ability of markets was emphasized. However, as the global financial and economic crisis has turned into the global employment crisis, the social consequences have started to top the policy agenda. With that turn, the debate on the appropriate role of the state in the economy, in providing regulatory framework as well as supporting job creation, has been revived. This paper contributes to this debate with insights from transition experiences. It illustrates that in countries where reforms of institutions and the business climate have been particularly costly and prospects for private job creation poor, the role of the state sector as an employer rises.

The theoretical model presented in this paper extends the framework of Brixiova and Kiyotaki (1997), who in turn build on the literature on industry evolution and job creation and destruction of Jovanovich (1983) and Hopenhayn and Rogerson (1993). Unlike Hopenhayn and Rogerson (1993) and more recently Foncesa, Lopez-Garcia and Pissarides (2001), who study a steady-state economy with an unlimited supply of potential entrepreneurs, this model considers a transition economy with a limited population of potential entrepreneurs. Moreover, by focusing on the 
prevailing business environment and its impact on forward looking entrepreneurs, the model complements Fonseca et al. (2001), who emphasize start-up costs. ${ }^{2}$

The paper is organized as follows. Section 2 provides the stylized facts on the economic restructuring and sets out the different reform trajectories that the CEEB and CIS countries have experienced so far. Section develops the model of transition with start ups responding to the business climate. Section 4 presents numerical experiments and illustrates the model's implications for productivity, structure of the private sector, and employment during transition. Section 5 conducts policy analysis and shows that the role of the state as an employer rises during the transition if reforms to the institutional set up are sluggish. Section 6 concludes.

\section{$2 \quad$ Stylized Facts}

This section summarizes the main macroeconomic trends that our theoretical model aims to capture, namely private sector growth, employment, unemployment, output, and labor productivity. It also briefly discusses policies and institutions, which contributed to these trends. The CEED economies are compared with non-oil exporting countries of the CIS ${ }^{3}$.

\subsection{Similar starting conditions, divergent paths}

At the outset of the transition, the CEEB and non-oil CIS countries exhibited similar structural conditions as they all started from central planning and were dominated by corporate and financial structures shaped by the socialist system. In 1990, these countries had a low share of the private sector in GDP, lacked competition policy and a well functioning two-tiers banking system. The institutional set up and the business climate in particular were characterized by rigidities and excessive regulations. The composition of production was skewed towards industry and agriculture, whilst services occupied a limited role in GDP compared to other countries at a similar level of development (Figure 1).

Figure 1. Initial structural conditions in 1990

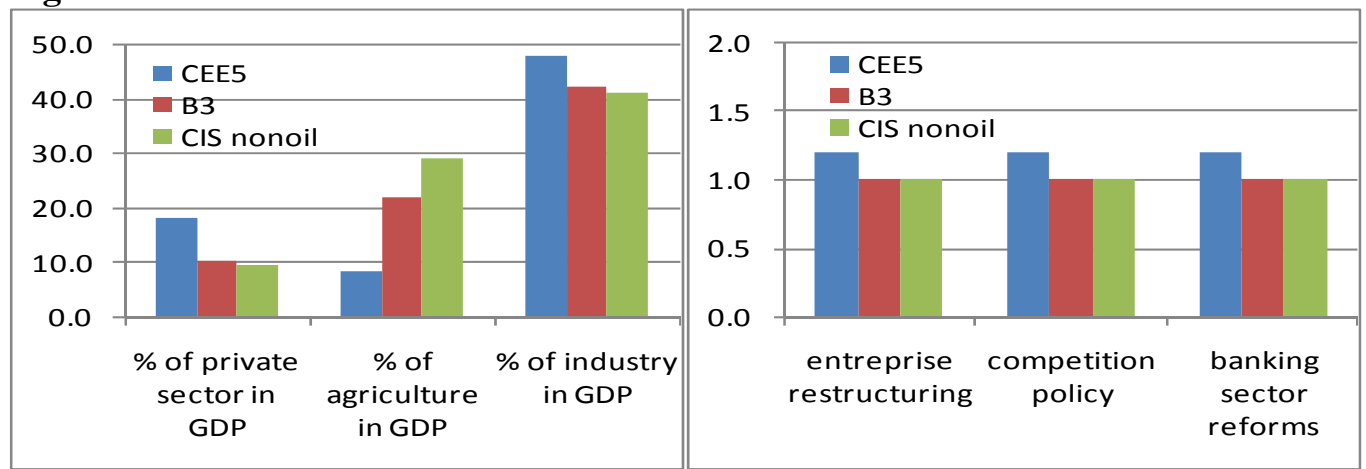

Source: Authors' calculations based on data drawn from the World Bank’s World Development Indicators and EBRD transition indicators. Note: The EBRD indicators increase from 1 (little or no change from a rigid centrally planned economy) to 4 or more (standards of an industrialized market economy).

\footnotetext{
${ }^{2}$ While job matching frictions also played a role, the low vacancy-unemployment ratios prevailing in most countries point to the scarcity of entrepreneurs as the primary constraint to job creation.

${ }^{3}$ CEE-5: Czech Republic, Hungary, Poland, Slovakia and Slovenia, the Baltic-3: Estonia, Latvia and Lithuania; non-oil CIS: Armenia, Belarus, Georgia, Kyrgyz Republic, Moldova, Tajikistan and Ukraine. Discussion of the cases of Belarus and Estonia is in Annex I.
} 
From a macroeconomic point of view, the CEEB and non-oil CIS countries started transition with enforced full employment, limited foreign trade and artificially low inflation rates. The liberalization of prices and foreign trade (the so-called type 1 reforms) in the early 1990s resulted in very high inflation rates and unsustainable current account deficits. Therefore, policy makers initially focused on establishing macroeconomic stability. The CEEB countries managed to bring inflation rates to low 2-digit territories by the mid-1990s, while the stabilization took longer in non-oil CIS countries (Svejnar, 2001; EBRD, 2005).

The CEEB and the non-oil CIS countries differed in the speed and scope with which "type-2 structural reforms" were put in place. "Type 2" reforms consisted mainly of measures key for establishing conditions for private sector development and growth: corporate restructuring, a well functioning competition authority, administrative reforms, development of a commercial banking sector and effective tax system, infrastructure, labor market regulations, and establishment and enforcement of a market-oriented legal system and accompanying institutions. ${ }^{4}$ CEEB countries adopted these structural measures faster and also paid a much greater attention to the quality of the framework (Figure 2a). ${ }^{5}$ As a result, the business climate has become more competitive in the CEEB than in the CIS countries, as also evidenced by mark-up indexes (Figure 2b).

More generally, the CEE-5 and in particular the Baltic countries were placed well above the nonoil CIS countries in various rankings of competitiveness and the quality of the business climates. These include the EBRD's transition index, the World Bank's Doing Business 2008 and Governance, the Institute for Management Development 2007 competitiveness report, the Cato's Institute Index of Economic Freedom, and the index of the Transparency International. ${ }^{6}$

Figure 2a. The timing and scope of structural reforms, 1990-2007
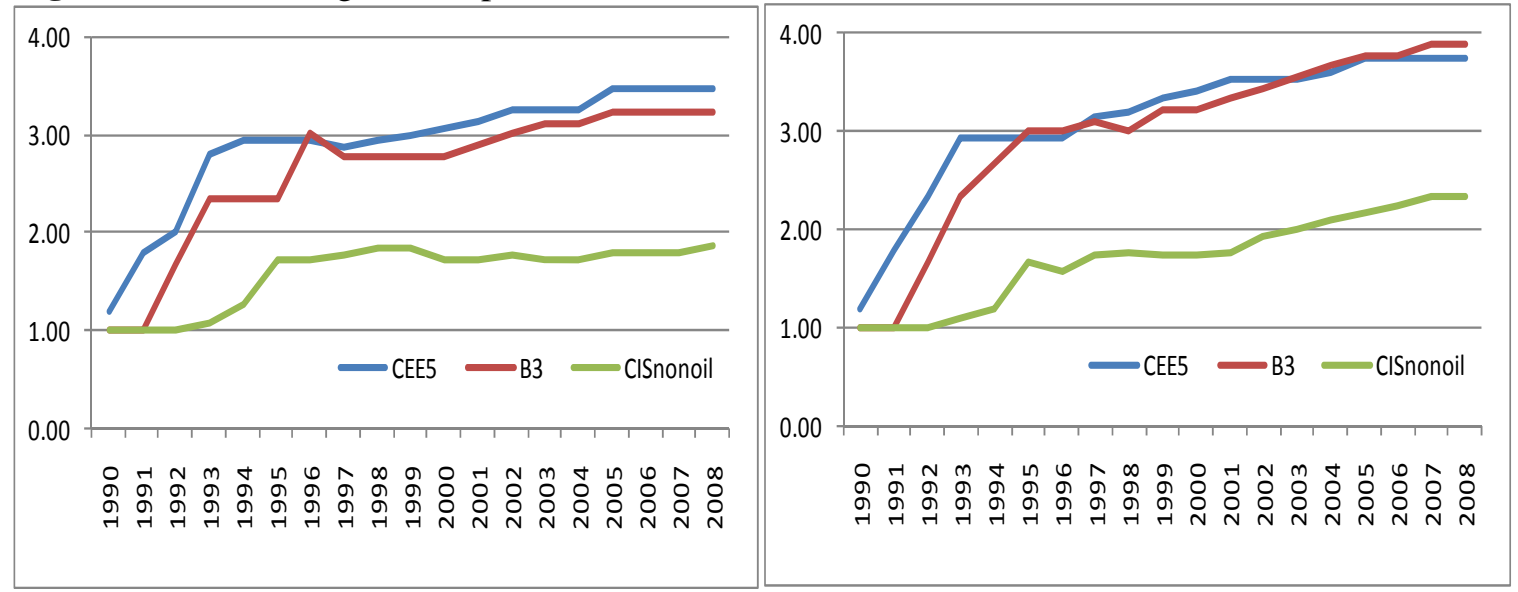

Source: Authors' calculations based on data drawn from the EBRD transition indicators. Averages are arithmetic averages.

${ }^{4}$ According to Aidis, Estrin and Mickiewicz (2007), these institutions, together with access to credit, are crucial for an environment conducive to entrepreneurship.

${ }^{5}$ Roland (2004) classifies institutions into slow-moving (changing slowly and continuously) and fastmoving (changing rapidly and irregularly), and underscores the need for further research on the role of values and norms in shaping both ideas and institutions.

${ }^{6}$ Conceptual issues related to the World Bank's Doing Business and similar indexes were raised (Arrunada, 2007 and others). Alternative measures also point to the same overall results for these two country groups. 
Figure 2b. Mark up index, 1990 - 2003

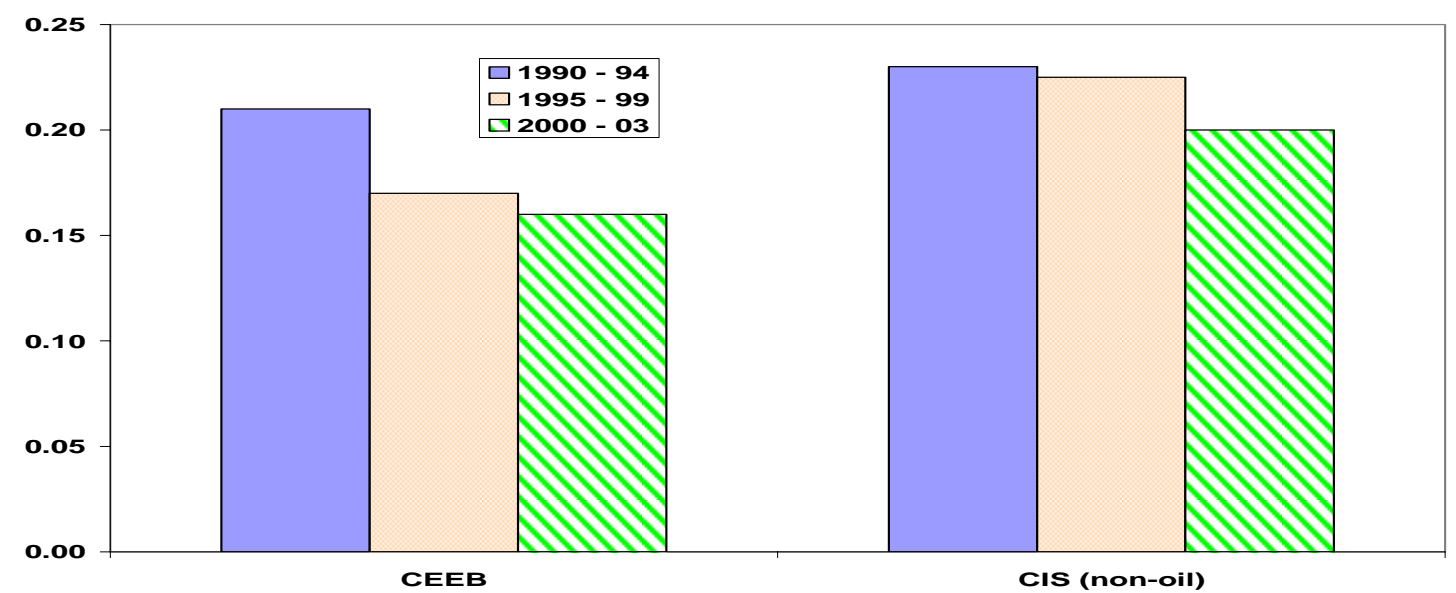

Source: EBRD (2008).

As Aidis (2003) states, “...productive entrepreneurship cannot be taken for granted in transition countries, and is influenced both by the current institutional weakness, as well as by historical legacies." Regarding institutions, EBRD (2008) showed a link between product market competition and growth; higher competition (approximated by lower mark-ups) is associated with higher firm entry and productivity. Bastos and Nasir (2004) found that the competitive pressure is the most critical factor of the investment climate for firm-level productivity.

\subsection{Private sector growth}

Successful transition from plan to market has depended critically on the emergence of a dynamic private sector. In the first stage, privatization and restructuring of public enterprises was mostly associated with short-term job destruction and slow growth in productivity and output. Over time, privatized firms have contributed to job creation and growth by using resources more efficiently. With substantial lowering of entry barriers, the de novo private small and medium enterprises tend to drive the recovery of output, employment, and labor productivity ${ }^{7}$.

Aslund and Johnson (2004) emphasized that even small differences in policies towards small and medium-sized enterprises (SMEs) can have a strong impact on private sector growth in transition economies. ${ }^{8}$ In that context, the early 1990s reforms of the economic and legal environments and the straightforward and transparent rules for firm creation in Central and Eastern Europe contributed to acceleration in the number of SMEs (Smallbone and Venessar, 2004). Figure 3 indicates that a higher number of SMEs per capita is associated with higher private sector output.

\subsection{Structural transformations}

As many new private firms were created in the service sector and to a lesser degree in manufacturing, rapid private sector growth was accompanied by a sectoral shift. A sectoral shift

\footnotetext{
${ }^{7}$ Studies linking entrepreneurship and firm creation with output and employment growth in transition include Johnson and Loveman (1995), Bilsen and Konings (1998), McMillan and Woodruff (2002), Faggio and Konings (2003), Berkowitz and DeJong (2005), and Rutkowski et al. (2005).

${ }^{8}$ Using a database of European firms, Klapper, Laeven and Rajan (2006) also find that costly entry regulations hamper the creation of new firms, especially in industries that should naturally have high entry.
} 
occurred as a correction of imbalances inherited from central planning, where the service sector in all countries was underdeveloped in comparison to countries with similar income levels. Specifically, in 1990, industry took a disproportionately large share of output and employment in all countries, and agriculture played an important role in the Baltic and CIS countries. Transition everywhere has been characterized by labor reallocation from industry and agriculture towards services, especially in the early $1990 \mathrm{~s}^{9}$. The shift towards services and away from agriculture was more marked in the CEEB as compared to the CIS countries (Figure 4).

Figure 3. Private sector output and SMEs
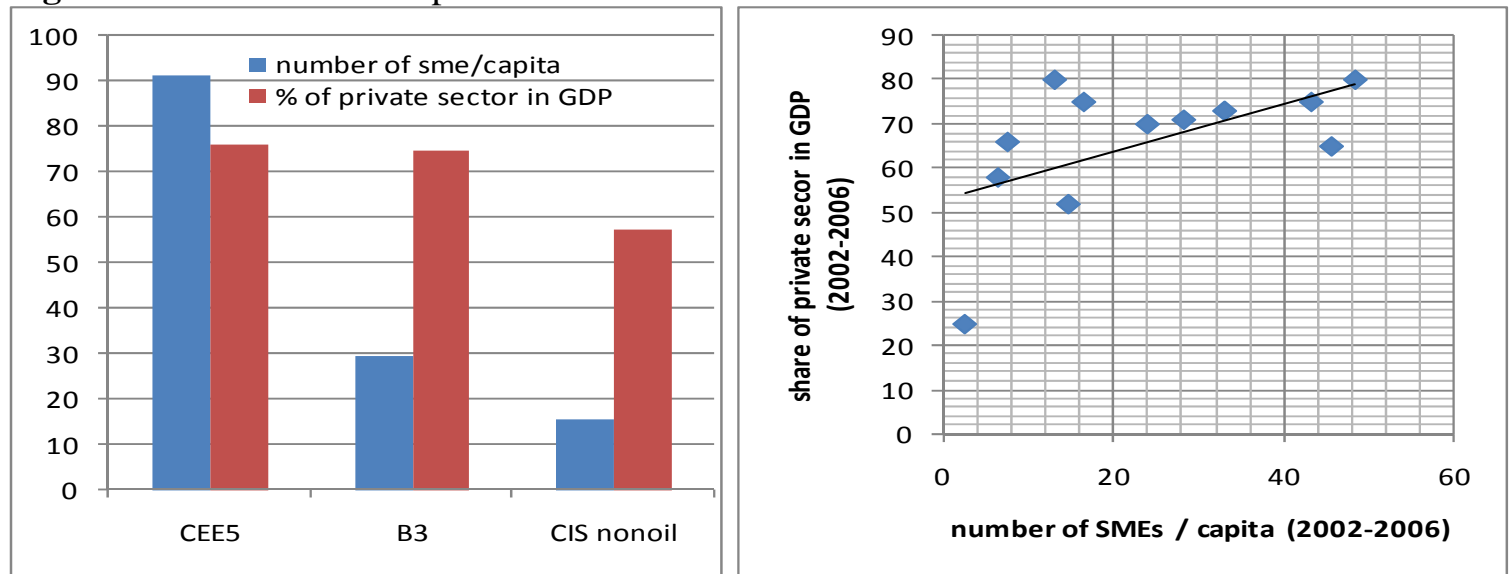

Source: Authors' calculations based on data drawn from the World Bank's World Development Indicators and EBRD transition indicators

Note: The private sector share in GDP is an arithmetic average over 2002 and 2006. The number of SMEs per capita refers to the year for which this indicator is available between 2002 and 2006.

Figure 4. A shift away from agriculture and industry towards services
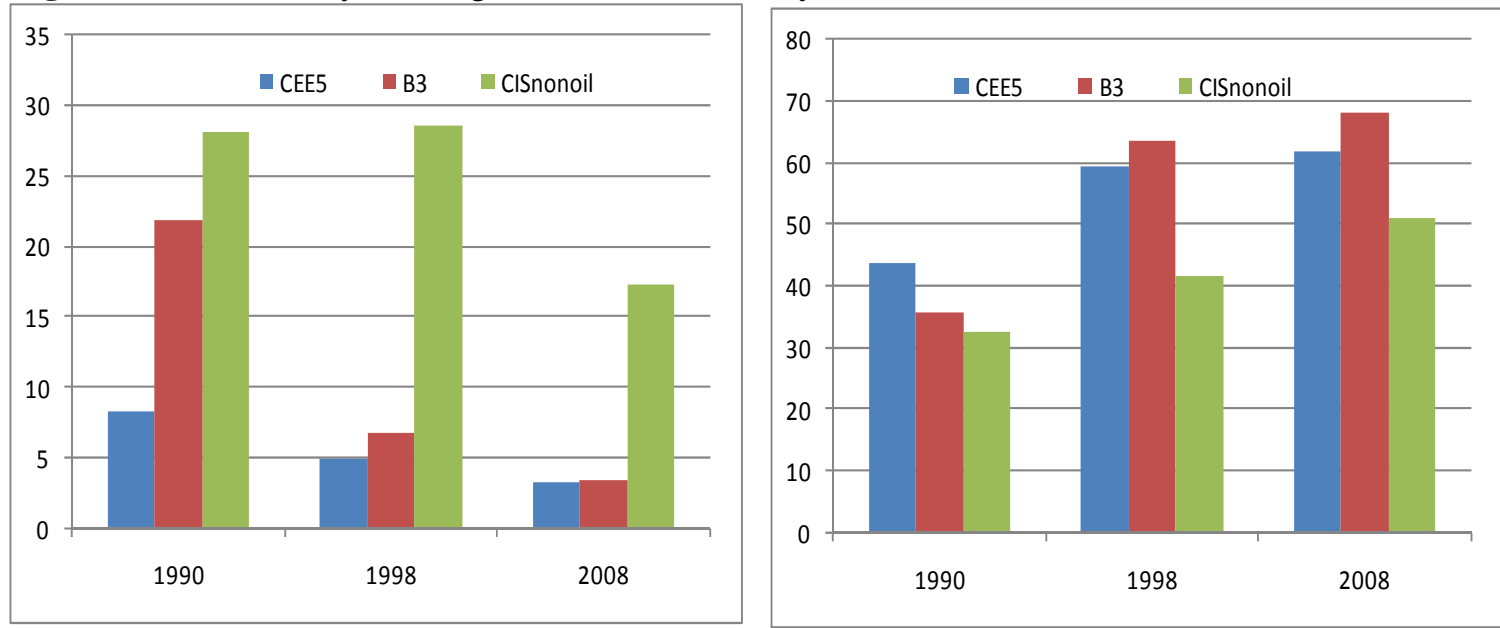

Source: Authors' calculations based on data drawn from the World Bank’s World Development Indicators World Development Indicators. Averages are arithmetic averages.

The decrease in the share of industry and manufacturing in GDP is very similar across the three country groups (Central and Eastern Europe, the Baltics, and non-oil CIS). In 2006, industry

\footnotetext{
${ }^{9}$ In the late 1990s, when the structures of the Baltic economies approached those of the EU-15 countries, job reallocation occurred mostly within sectors (Fabbio and Konings, 2003, Jurajda and Terrell, 2008).
} 
accounted for about 30\% and manufacturing for $20 \%$ of GDP in all three groups. Yet, the composition of manufacturing products changed markedly in Central and Eastern Europe, while it remained mostly unchanged in the CIS. Composition of production shifted towards highertechnology products in Central and Eastern Europe and to a lesser degree in the Baltics, but the average high-technology content of CIS exports declined between 1996 and 2006 (Figure 5). In summary, also within the group of SMEs, the share of "high productivity" enterprises has been increasing more rapidly in CEEB countries than in the non-oil CIS countries.

Figure 5. The high-technology content of exports, in 1996 and 2006

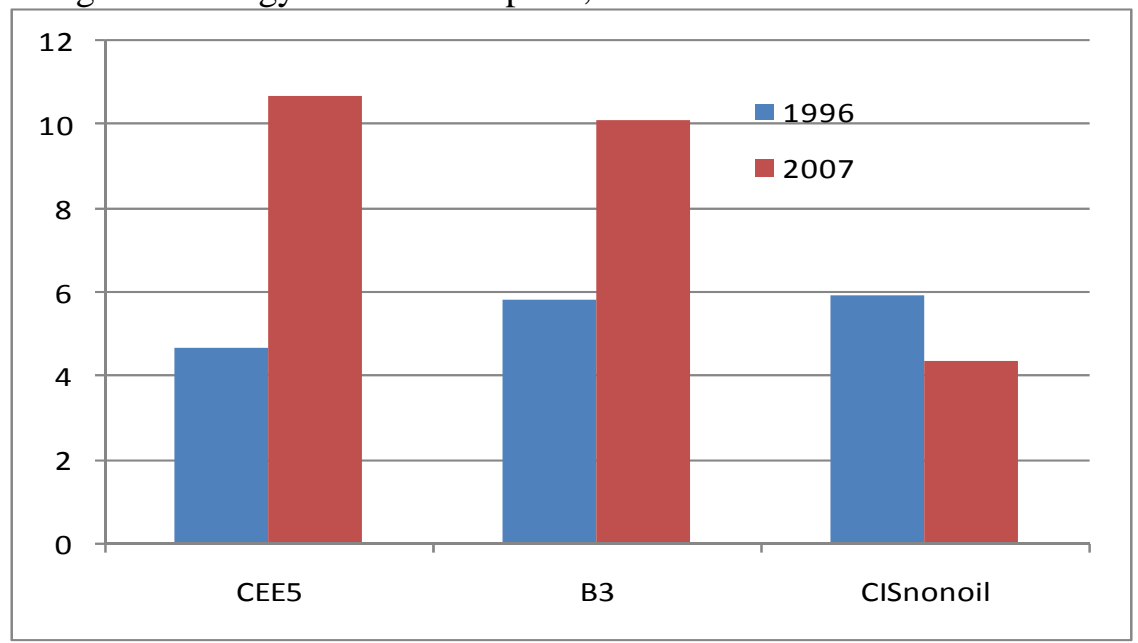

Source: Authors' calculations based on data drawn from the World Bank's World Development Indicators World Development Indicators. Averages are arithmetic averages.

\subsection{Productivity paths}

The transition outcomes reflect broadly the diverging reform paths. The transitional recession of the early 1990s was shorter in the CEEB, with their real GDP picking up much earlier than in the non-oil CIS group (Figure 6). For instance, real economic activities reached their 1990 levels already in 1997 in the CEE-5, while the non-oil CIS countries still remained below their 1990 levels even in 2007. A similar pattern has emerged for economy-wide productivity developments.

Figure 6. Real GDP $(1990=100)$ and economy-wide productivity $(1991=100), 1990-2007$
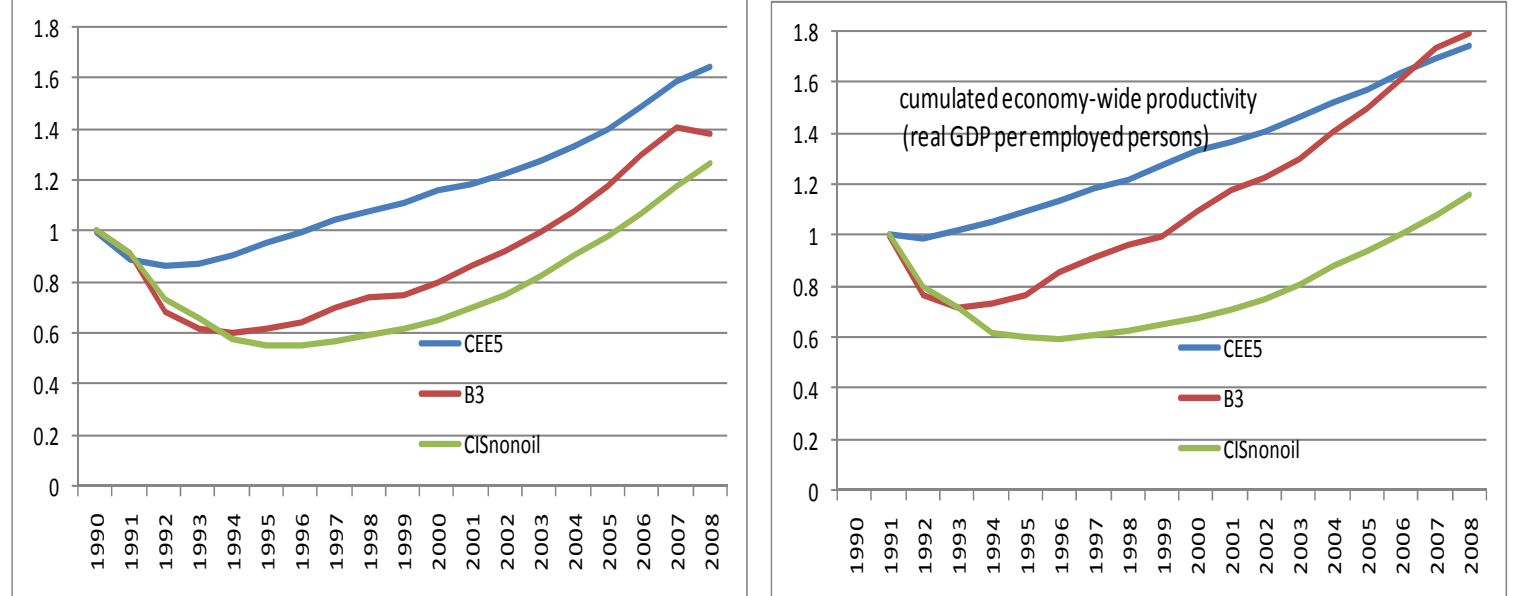

Source: Authors' calculations based on data drawn from the World Bank's World Development Indicators. Group averages are arithmetic averages. 


\section{The Model}

\subsection{Environment}

The model below shows how the quality of institutions, including the business climate, affects the entrepreneurs' choice of the type of firm (or technology) they operate and consequently the output, employment, and productivity during transition and in the steady state. ${ }^{10}$

In this model, economic transition consists of labor relocation from the state sector to the private sector. The population is normalized to one and consists of entrepreneurs and workers, with population shares $\mu$ and $1-\mu$, respectively. All agents live forever, are endowed with one unit of time every period, and have the same risk neutral preferences, $E_{0} \int_{t=0}^{\infty} e^{-r t} c_{t} d t$, where $c_{t}$ is consumption of a single good in period $t$, and $E_{0}$ denotes the expectations agents form at period 0 about their consumption in period $t$.

All agents are initially working in the state sector, that is $s_{0}=1$. The state sector jobs decline over time at an exogenous rate $\lambda$, that is $\dot{s}=-\lambda s$. New jobs arise in the private sector, where they are created through a costly effort of entrepreneurs, $x$. The search effort costs entrepreneurs $d(x)=x^{2} / 2 \gamma, \gamma>0$ units of consumption good and leads to a rate $x$ of finding a business opportunity. Thus as the size of the state sector decreases, agents become involved in the newly created private sector, either as entrepreneurs or workers.

The single consumption good can be produced by one of the three technologies: $0<z_{s}<z_{l}<z_{h}$, where $z_{s}$ is the technology in the state sector, and $z_{h}$ and $z_{l}$ are the highproductivity and low-productivity technologies in the private sector. ${ }^{11}$ They also differ in units of labor required per unit of output. The profitability of each business opportunity depends upon both its productivity (high or low). The business opportunity that the entrepreneur receives is of high productivity, $z_{h}$, with probability $\phi$ and of low productivity, $z_{l}$, with $1-\phi$. In addition to search effort, each entrepreneur also chooses whether to take the opportunity that arrives or to search for a more profitable one. In each period, the business opportunity allows entrepreneurs to produce output $y_{i t}$ using $n_{i t}$ amount of labor according to $y_{i t}=z_{i t} n_{i t}$, where $z_{i t}$ denotes the business capital in a firm with productivity (technology) $i, i=h, l$ (high or low). ${ }^{12}$ Rigidities in the business environment at $t$ are treated as a "tax" on high-productivity businesses, $\theta_{t}$, and are reduced during the transition at rate $\omega, \dot{\theta}=-\omega \theta$. Alternatively, the quality of business

\footnotetext{
${ }^{10}$ This paper does not try to explain differences in transition paths between the Central Europe and countries and the Baltics caused by availability of credit, which played role especially around mid-2000s. While important, this topic is left to further research.

${ }^{11}$ This model does not explain the reasons behind the low productivity in the state sector. Bajona and Locay (2009) develop a model of entrepreneurship under central planning that accounts for the difference in long-run performance between planned economies and market-oriented ones.

${ }^{12}$ Since this paper focuses on drivers of productivity growth during transition, it does not try to explain why some countries adopted better business environment or institutional set ups faster than others.
} 
environment could be characterized by an efficiency component, $E=1-\theta$. The firm's effective business capital (productivity) thus becomes $\bar{z}_{h}=(1-\theta) z_{h}=E z_{h}$, where $z_{h}$ is the technology component and $E=1-\theta$ is the efficiency component of the business capital (or productivity). ${ }^{13}$

Let $\left(1-s_{t}\right) \mu$ be the total number of entrepreneurs at time $t$ outside the state sector. Then entrepreneurs searching for business opportunities, $m_{u t}$, and operating business, $m_{t}$, satisfy:

$$
\left(1-s_{t}\right) \mu=m_{u t}+m_{t}=m_{u t}+m_{h t}+m_{l t}
$$

with $m_{t}=m_{h t}+m_{l t}$, where $m_{i t}$ are entrepreneurs operating business of productivity $i, i=h, l$. The number of entrepreneurs running high and low productive businesses evolves according to:

$$
\begin{aligned}
& \dot{m}_{h t}=x_{t} \phi\left[\mu\left(1-s_{t}\right)-m_{h t}-m_{l t}\right]-\delta m_{h t} \\
& \dot{m}_{l t}=x_{t} p(1-\phi)\left[\mu\left(1-s_{t}\right)-m_{h t}-m_{l t}\right]-\delta m_{l t}
\end{aligned}
$$

where $p$ is probability that the searching entrepreneurs accept low productive business opportunities. Moreover, $m_{h 0}=m_{l 0}=0$, that is no entrepreneurs run businesses in period 0 .

The total labor in the private sector, $\left(1-s_{t}\right)(1-\mu)$, consists of workers employed in highly productive businesses, $\bar{n}_{h t}$, low productive businesses, $\bar{n}_{l t}$, and the informal sector, $N_{u t}:{ }^{14}$

$$
\left(1-s_{t}\right)(1-\mu)=N_{u t}+n_{t}=N_{u t}+m_{h t} \bar{n}_{h}+m_{l t} \bar{n}_{l} .
$$

Suppressing the time subscripts, let $J^{h}, J^{l}$ and $J^{u}$ be the values of the entrepreneur operating a highly productive private firm, a low productive private firm, and searching for a business opportunity, respectively. The corresponding Bellman equations are given by:

$$
\begin{gathered}
r J^{h}=\pi_{h}-\delta\left(J^{h}-J^{u}\right)+\dot{J}^{h} \\
r J^{l}=\pi_{l}-\delta\left(J^{l}-J^{u}\right)+\dot{J}^{l} \\
r J^{u}=\max _{x}\left(-\frac{x^{2}}{2 \gamma}+x\left[\phi\left(J^{h}-J^{u}\right)+(1-\phi) \max _{p \in[0 ; 1]} p\left(J^{l}-J^{u}\right)\right]\right)+\dot{J}^{u}
\end{gathered}
$$

\footnotetext{
${ }^{13}$ This assumption is along the lines of Rodrik (2008) who posits that "bad" institutions tax tradables more than non-tradables. Production systems tend to be more complex in tradables, which makes firms in that sector more dependent on the institutional framework, especially on contracts and reliable third-party enforcement. In the context of the presented model, it is assumed that highly productive firms carry out more complex activities. Results would not change if "taxes" on low productive businesses were imposed.

${ }^{14}$ The output per worker in the informal sector amounts to $Z_{u t}$, where $Z_{u}<Z_{l}$. For analysis of how size of firms changes with productivity changes and development, see Gollin (2008).
} 
with $J^{l}>J^{u} \Rightarrow p=1$ and $J^{l} \leq J^{u} \Rightarrow p=0 ; \quad \pi_{l}=z_{l} \bar{n}_{l}-w_{l} \bar{n}_{l} ; \pi_{h}=(1-\theta) z_{h} \bar{n}_{h}-w_{h} \bar{n}_{h}$, and $\dot{J}^{i}$ denoting change in $J^{i}$ over time, $i=h, l$. Wages in the private sector, $w_{p}$ are fractions of output, i.e. $w_{p l}=\phi z_{l}, w_{p h}=\phi z_{h}$, and are above the income (marginal product) in the informal sector. ${ }^{15}$ Equations (5) and (6) state that the return from operating a private firm consists of profits plus the change of the value of running a firm over time. According to (7), the return from searching for a business opportunity equals the net expected return from running a business plus the change of the value of searching.

\subsection{Solution}

The entrepreneur chooses the search intensity, $x$, and accepts the low productivity business opportunity with probability $p=\bar{p}$ so that the marginal cost of search equals to the expected marginal payoff. Denoting $L=\phi\left(J^{h}-J^{u}\right)+(1-\phi) \bar{p}\left(J^{l}-J^{u}\right)$ to be the "value" of a random business opportunity to an entrepreneur, this implies $x=\gamma L$. For each entrepreneur, the "profit" from searching, $\pi_{u}$, becomes $\pi_{u}=\gamma L^{2} / 2$. From (5) - (7), $L$ evolves according to:

$$
\dot{L}=(r+\delta) L-\phi\left(\pi_{h}-\pi_{u}\right)-(1-\phi) \bar{p}\left(\pi_{l}-\pi_{u}\right)
$$

where $\bar{p}=1$ if $\pi_{l}>\pi_{u}$, and $\bar{p}=0$ if $\pi_{l}<\pi_{u}$, and $\bar{p}=0 \Leftrightarrow \pi_{l}=\pi_{u}$, i.e. the entrepreneur operated the low-productive business as long payoff of doing so exceeds that of continued search.

The equilibrium transition path for total number of entrepreneurs, that is those operating high and low productivity firms, thus becomes:

$$
\dot{m}=\gamma L[\mu(1-s)-m]-\delta m
$$

where $m_{0}=0, m=m_{h}+m_{l}$. The dynamics in $L$ is thus caused by changes in the "tax" on the business environment, $\theta$, as well as by changes in probability to operate low productivity business. For a given $\theta$ More specifically:

$$
\begin{aligned}
& \dot{m}=\gamma L[\mu(1-s)-m]-\delta m ; m_{h}=\phi m ; m_{l}=(1-\phi) m \text { when } p=1 \\
& \dot{m}_{h}=\gamma L\left[\mu(1-s)-m_{h}\right]-\delta m_{h} ; m_{l}=0, \text { when } p=0 \\
& \pi_{l}=\frac{\gamma}{2} L^{2} \text { when } p \in(0,1)
\end{aligned}
$$

where for a given level of business environment $\theta$

$$
L=\frac{\phi\left(\pi^{h}-\pi^{u}\right)+(1-\phi) p\left(\pi^{l}-\pi^{u}\right)}{r+\delta}=\frac{-(r+\delta)+\sqrt{(r+\delta)^{2}+2 \gamma\left[\phi \pi_{h}+(1-\phi) p \pi_{l}\right]}}{\gamma[\phi+(1-\phi) p]}(10)
$$

\footnotetext{
${ }^{15}$ Temple (2005) provides a rationale and derivation of this formulation, based on skill differences between workers in the formal and informal sectors.
} 
The dynamic competitive equilibrium is characterized by the path of $(L, p, m)$ satisfying (8) and (9). Equation (9) and its components shows that for given state sector employment and the private firms, the private sector grows more rapidly in an enabling business environment.

\section{Characterizing transition with the phase diagram}

Before turning to simulation results, the phase diagram below illustrates in further detail the impact of business environment on the speed of the private sector development for the special case of the immediate state sector closure and constant business environment. The impact of business environment on both transition and steady state can be seen directly from (9), where the comparative statics is as follows: $L=L\left(\gamma, \theta, z_{i}, \phi, \delta\right)$. With improvement of the business environment, i.e. with lower $\theta$, both the size of the private sector in the steady state and the rate of the private sector creation increase.

Transition paths of $m$ and $L$ for this case are depicted in Figure 7. The saddle path is the locus along which $L$ is constant at its steady-state value. While the control variable $L$ jumps immediately to its steady state value, the state variable, $m$, gradually converges to the steady state according to (9). ${ }^{16}$ As $\mathrm{L}$ increases with the improvement of the business environment, so does the search of entrepreneurs and the rate of firm creation, as well as its steady state value.

Figure 7 shows a phase diagram of the transition economy for the case in which the entrepreneurs take all the business opportunities they find during the entire transition, as long as the institutions/business climate is characterized by $\theta_{1}$ (and hence leads to the equilibrium search effort $\left.\gamma L_{1}\right)$. The condition for $\mathrm{p}=1\left(\pi_{l}>\pi_{u}\right)$ holds in the region below the $\pi_{l}=\pi_{u}$ area (ranging from $L^{*}$ to $L^{* *}$. In contrast, if the business environment is described by $\theta_{2}<\theta_{1}$, the associated steady state is located above $\pi_{l}=\pi_{u}$ area. The entrepreneurs will thus be accepted only the high productivity opportunity, if $\theta_{2}$ holds throughout the transition. If business climate improves gradually during the transition from $\theta_{1}$ to $\theta_{2}$, then entrepreneurs will initially accept running both types of businesses, accept some of the low productive opportunities while in the $\pi_{l}=\pi_{u}$ area, and accept only high productive opportunities at the end of the transition. ${ }^{17}$

\footnotetext{
${ }^{16}$ In the steady state, if the after-tax productivity gap between high and low productive businesses is relatively large, the entrepreneurs run only highly productive businesses, i.e. $p=0$. If the gap is small, they run both types of businesses, i.e. $p=1$. Under the immediate state sector closure the number of searching entrepreneurs, $m_{u}$, shrinks as quickly as the number of entrepreneurs running firms, $m$, expands.
}

${ }^{17}$ The productivity transition path thus depends partly on the timing of entrepreneurs' choice of the type of firm to operate (technology). In this respect, the model is somewhat related to Parente and Prescott (2000). 
Figure 7. Phase diagram for the state variable $(\mathrm{m})$ and the control variable $(\mathrm{L})$

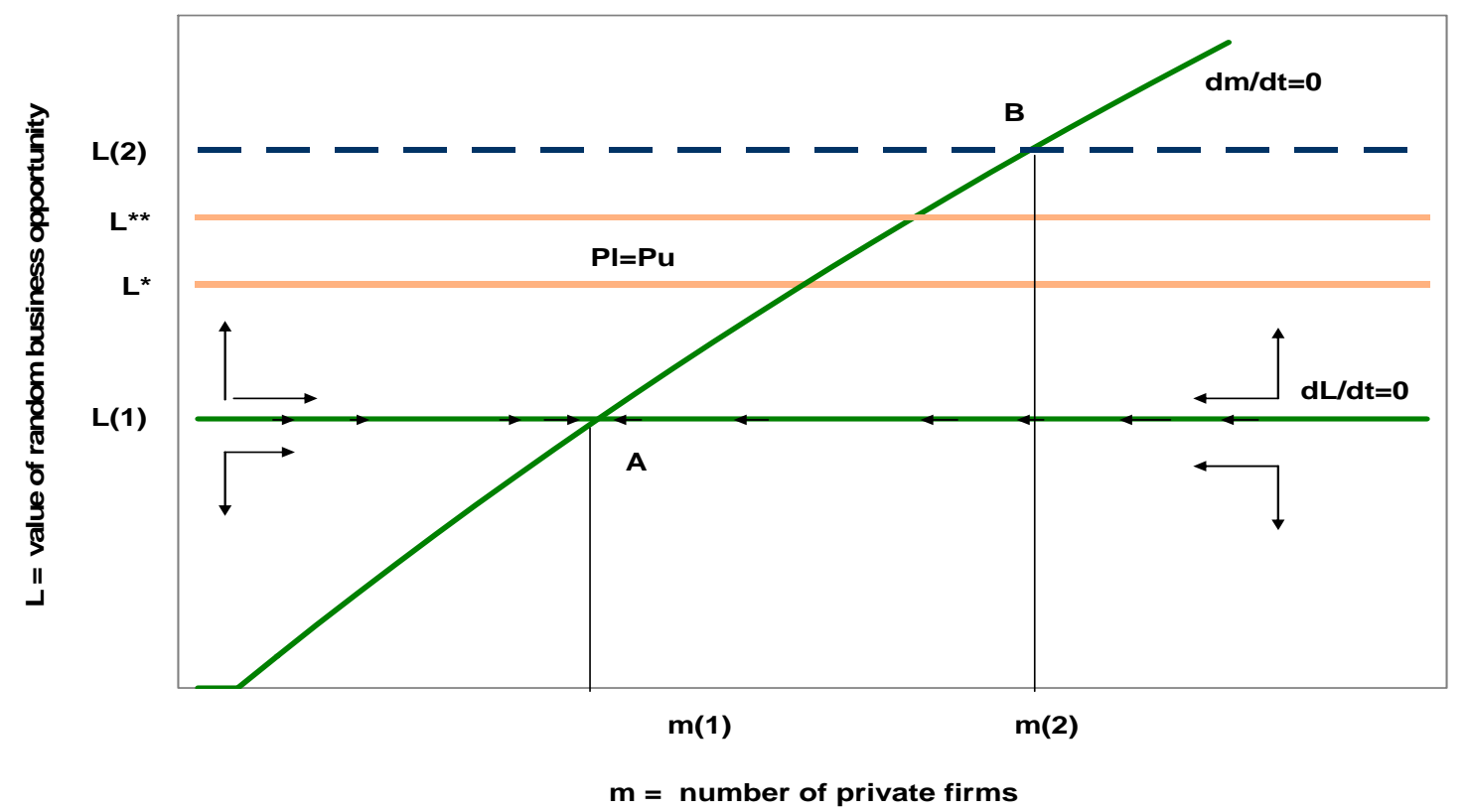

\section{$4 \quad$ Numerical Experiments}

This section presents results of the model that are broadly consistent with developments in transition economies over the past 20 years. In particular, the model simulations illustrate the impact of business environment on the firm start-ups, unemployment and labor productivity. The time period is one year. Other baseline parameters are chosen to broadly reflect some aspects of the annual observations from the transition countries', EBRD and OECD statistical databases:

\section{Table 1. Parameters of the model}

\begin{tabular}{|c|c|c|}
\hline Variable & Value & Source \\
\hline share of entrepreneurs in population $\mu$ & 0.2 & OECD LF Statistics \\
\hline annual real interest rate $r$ & 0.04 & Standard \\
\hline rate of destruction of private jobs $\delta$ & 0.15 & Standard (van Ours, 2007; Statistics Estonia, others) \\
\hline rate of the state sector closure, $\lambda$ & 0.3 & EBRD \\
\hline average output in low productive firm $Z_{l}$ & 1 & Normalized \\
\hline wage in the private sector $w$ & 0.5 & Set to amount to $1 / 2$ of output (within standard rage) \\
\hline average output in highly prod. firm $Z_{h}$ & 4 & Set so that steady state productivity gap is $50 \%$ \\
\hline income in the informal sector $b$ & 0.2 & Set to amount to $40 \%$ of private wage \\
\hline efficiency of entrepreneur's search $\gamma$ & 0.11 & $\begin{array}{l}\text { Set so that steady state unemployment with high prod. } \\
\text { firms only is } 9 \%\end{array}$ \\
\hline share of high productive firms $\phi$ & 0.65 & $\begin{array}{l}\text { Set so that the average size of SME is } 4 \text {, as in the } \\
\text { Czech Rep. (European Commission 2008) }\end{array}$ \\
\hline employment in high productive firm $\bar{n}_{h}$ & 6 & $\begin{array}{l}\text { Set so that the highly prod. firm employs twice as many } \\
\text { more employees than low prod. firm }\end{array}$ \\
\hline employment in less productive firm $\bar{n}_{l}$ & 3 & $\begin{array}{l}\text { Average size of small/micro enterprise (European } \\
\text { Commission, 2008) }\end{array}$ \\
\hline
\end{tabular}




\subsection{Steady state}

Table 2 shows the steady state values under two types of the institutional set up/business climate: (1) an enabling one, with the "tax" rate $\theta=0$ and (2) a weak one, with the "tax" rate $\theta=0.8$. The more enabling business environment encourages potential entrepreneurs (1) to increase their search effort, and (2) to open only high productive businesses. Under the above parameters, because the highly productive firms employ more workers, both employment and labor productivity are higher when the business environment is conducive to firm start-ups.

Table 2. Steady state results - comparison of outcomes under different business environments

\begin{tabular}{lrr}
\hline & $\begin{array}{c}\text { Rigid } \\
\text { bus. climate }\end{array}$ & \multicolumn{2}{c}{$\begin{array}{l}\text { Enabling } \\
\text { bus. climate }\end{array}$} \\
\hline Total share of private firms & 13.9 & 11.8 \\
Share of high-productivity firms & 9.0 & 11.8 \\
Share of low-productivity firms & 4.9 & 0.0 \\
Share of searching entrepreneurs & 6.1 & 8.2 \\
Share of unemployed workers 1/ & 16.2 & 8.9 \\
Index of the average labor productivity & 2.44 & 3.12 \\
\hline
\end{tabular}

$1 /$ Includes workers in the informal sector.

Sensitivity analysis with respect to the following key parameter assumptions was carried out: (i) the share of high productive business opportunities, and (ii) productivity level in the high productive firm. Table 3 shows that the main results are robust to different assumptions:

Table 3. Sensitivity analysis under a rigid business climate

\begin{tabular}{lrrrr}
\hline & \multicolumn{2}{c}{ Productivity level in } & \multicolumn{2}{c}{ Share of highly } \\
& high productive firms & productive firms & \\
\% of LF & 3.5 & 4.5 & 0.6 & 0.7 \\
\hline Unemployment & 20.5 & 12.9 & 20.0 & 12.5 \\
Share of high prod. firms & 8.4 & 9.5 & 8.2 & 9.9 \\
\hline
\end{tabular}

\subsection{Transition}

\section{Improving the business climate}

Simulations below show the impact of the business climate on the labor market outcomes in transition, taking the rate of the state sector closure as given. The case where the poor environment persists ( $\theta=0.8$ ), i.e. the "tax" on the high-productivity firms remains high) is compared with the case where the environment improves, reflecting market reforms (the "tax" rate starts at $\theta(0)=0.8$ and follows $\dot{\theta}=-0 . \xi \theta$, where $\xi$ is the rate at which the environment improves. For both cases, the impacts on the size and the structure of the private sector, level of unemployment and its duration as well as on labor productivity are examined.

Figure 8a shows that with improvement of institutions and establishing more conducive business climate, during the transition the entrepreneurs shift from opening both high and low productive firms to opening only high productivity ones - this scenario approximates the case of the CEEB countries. The case of the non-oil CIS countries (Figure 8b) shows that when a poor business 
environment $(\theta=0.6)$ prevails, it induces firms to open both high and low productive firms during the entire transition. Thus substantial share of private firms are smaller and operating in low productive activities. Consequently, the aggregate unemployment can be also higher than under more enabling business environment scenario. Depicting different paths of labor productivity, Figure 8c shows that when the business climate is more enabling, the average labor productivity grows faster and its steady state value is higher than when the environment is rigid.

Figure 8a. Labor market paths where at the end of transition entrepreneurs run only the highly productive businesses, but at the early stages they run also the low productive ones

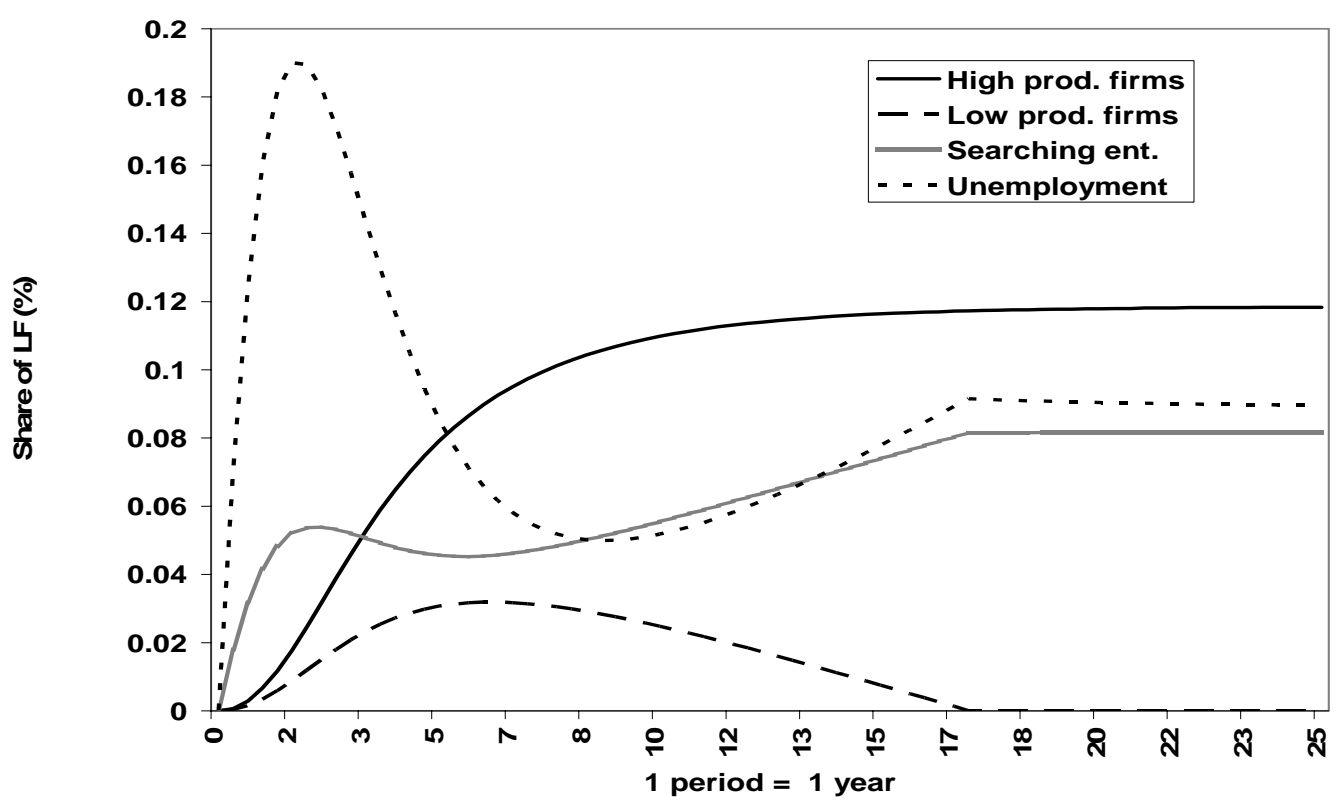

Figure 8b. Labor market transition paths where entrepreneurs operate both high and low productivity businesses throughout the transition

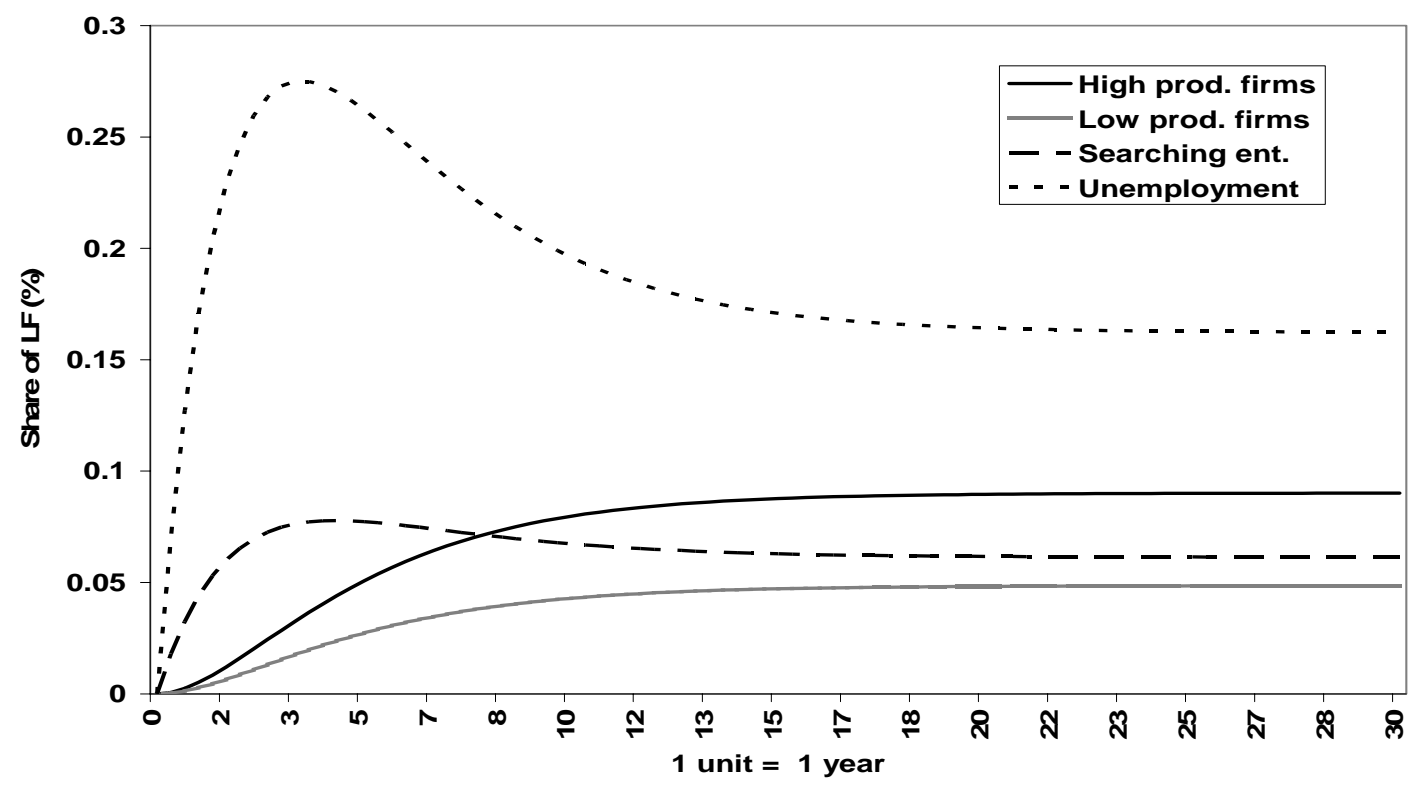


Figure 8c: Transition paths of labor productivity under different quality of business climate

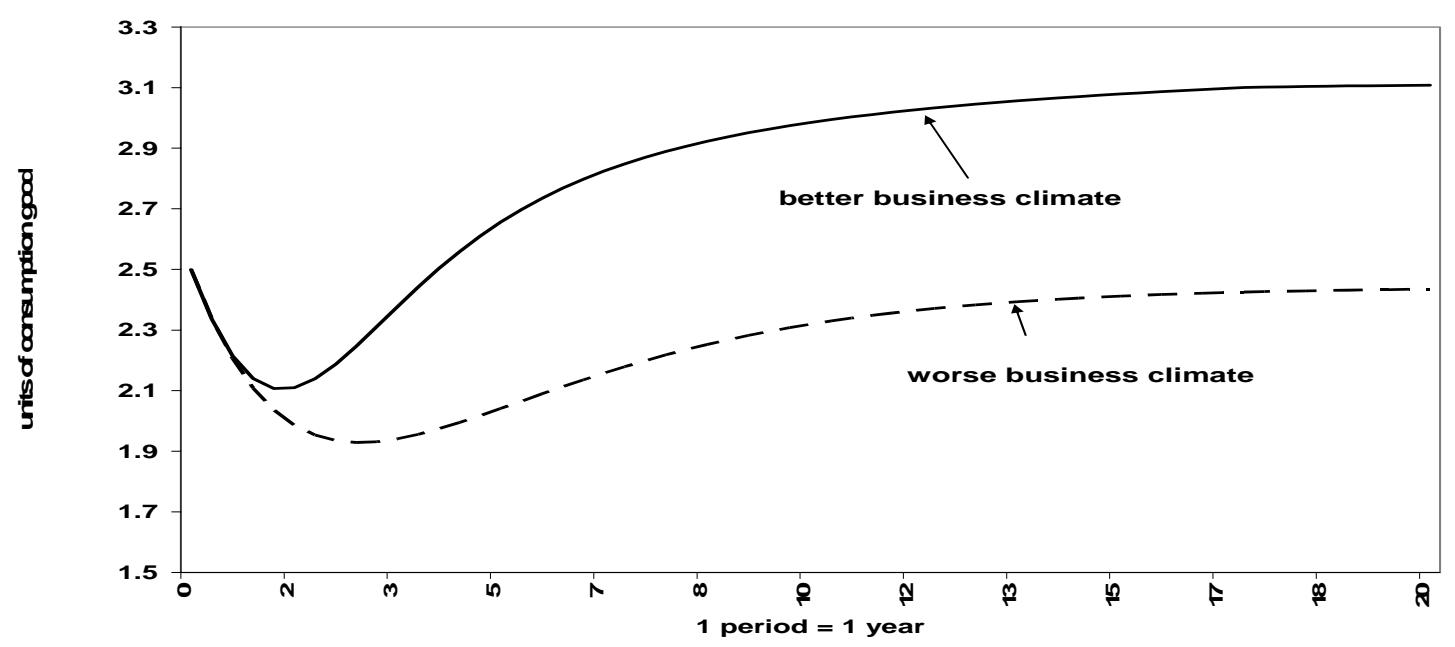

\section{Reducing entrepreneurs' search cost}

An alternative way to stimulate start ups is through reducing entrepreneurs' search costs/increasing their search efficiency. Such policies include training of entrepreneurs, assisting them with writing business proposals, and more broadly reducing entry barriers by streamlining registration and licensing. Since relative sectoral profits remain unchanged with lower search cost, these policies do not influence sectoral allocation of firms, but result in increased number of both high-productivity and low-productivity firms and reduced unemployment. ${ }^{18}$ Figures $8 \mathrm{~d}$ and 8e show the impact of reducing search cost by 20 percent on total number of firms and on unemployment when the business environment does not improve, i.e. $\theta=0.6$ prevails, and the entrepreneurs thus run both high and low productive firms throughout the transition.

Figure 8d. Impact of reduced search cost (by 20\%) on the share of private firms in LF

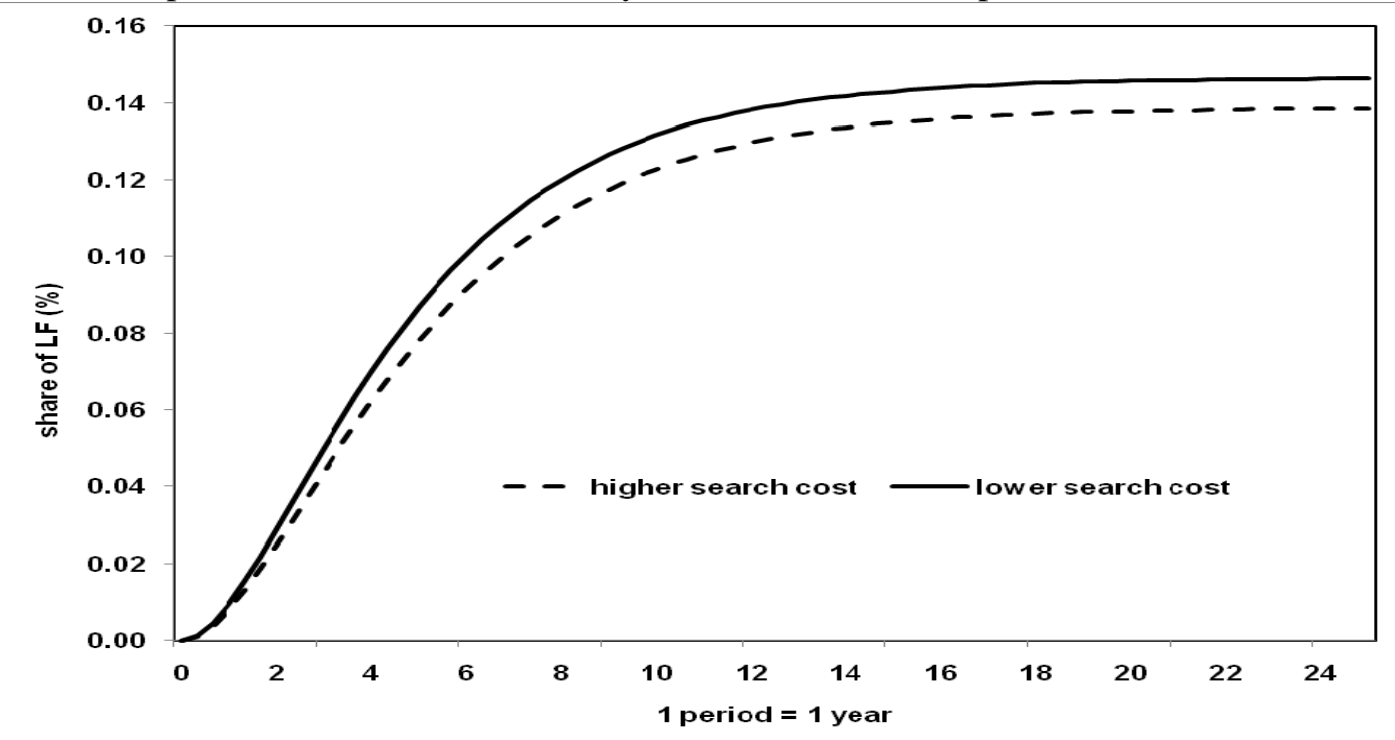

${ }^{18}$ These policies would influence sectoral allocation is if the government selected specific sectors where entrepreneurs' search would be eased. However, such approach would create problems of its own, due to imperfect information, and created incentives for rent seeking and inefficiencies. 
Figure 8e. Impact of reduced search cost (by 20\%) on the unemployment rate

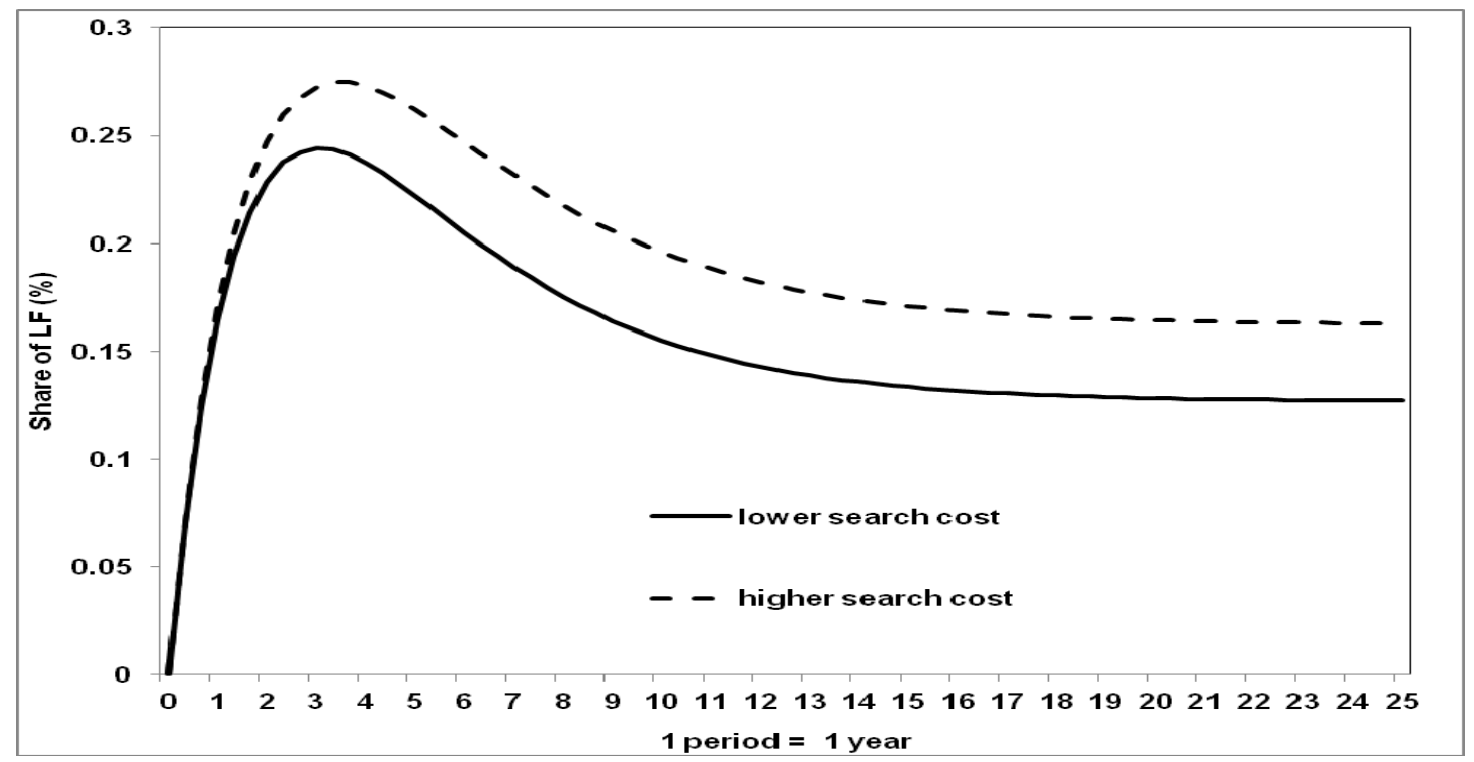

\section{$5 \quad$ Policy Analysis}

The above framework can address a related policy issue: the optimal size of the state sector employment during sectoral reallocation and with distortions in the business environment. An efficient allocation of state sector employment, private sector entrepreneurs and search effort $\{s, m, x\}$ maximizes the discounted expected utility of the representative agent. Given the standard assumption in the search literature that agents have risk-neutral preferences in consumption, this is equivalent to maximizing the discounted value of the aggregate output, $z_{s} s+(1-\theta) z_{p} m \bar{n}$, net of the total cost of searching for business opportunities, $m_{u} \frac{x^{2}}{2 \gamma}$, and net of the social cost of unemployment, $\frac{A}{2}[1-s-m \bar{n}-m]^{2}$. The net output is maximized subject to the law of motion for entrepreneurs (13) and the boundary conditions.

The social planner's problem therefore can be described as:

$\max _{m, s} \int_{0}^{\infty} e^{-r t}\left(z_{s} s+(1-\theta) z_{p} m \bar{n}-[(1-s) \mu-m] \frac{x^{2}}{2 \gamma}-\frac{A}{2}[1-s-m \bar{n}-m]^{2}\right) d t$

s.t.

$$
\dot{m}=x[(1-s) \mu-m]-\delta m
$$

and $m(0)=m_{0}, \lim _{t \rightarrow \infty} e^{-r t} \pi(t)=0$, where $\pi$ is the shadow value of the extra entrepreneur running a private firm. ${ }^{19}$

${ }^{19}$ Similarly to Burda (1993), the increasing marginal social costs of unemployment prevent the immediate state sector closure to be optimal, as the associated costs would be enormous. This section also assumes that the marginal product of workers in the informal sector is zero, without loss of results' generality. 
The solution is given by:

$$
\begin{aligned}
& z_{s}+A(1-s-m \bar{n}-m)=\mu \gamma \frac{\pi^{2}}{2} \\
& \dot{\pi}=-(1-\theta) z_{p} \bar{n}+z_{s}(1+\bar{n})+\pi(\delta+r)+\frac{\gamma}{2} \pi^{2}(1-\mu-\bar{n} \mu) \\
& \dot{m}=\gamma \pi[(1-s) \mu-m]-\delta m
\end{aligned}
$$

where $m(0)=m_{0}$.

Equation (15) states that the shadow value of the additional entrepreneur running a private firm is the discounted value of the difference in productivity between the state and the private sectors, net of the social costs of search. From (16) this value also determines the optimal value of the unemployment. Hence, the optimal size of the state sector employment is such that the unemployment level is also constant along the transition path. Finally, the optimal search effort and unemployment, together with $m_{0}$, then determine the unique optimal path of the number of entrepreneurs running private firms, as described by equation (16).

Together, (14) - (16) show that for a given level of state sector employment and number of entrepreneurs, the optimal rate of growth of the private sector is slower in a weaker business environment. Conversely, the optimal level of the state sector employment is higher the closer the productivity gap between the state and private sectors, the higher the social cost that the policymakers attach to unemployment, and with less enabling business environment.

Simulations of the optimal transition paths for different business environments show that the optimal rate of the state sector closure is slower under more distorted business environment than under a more enabling one (Figure 9). This is because with limited private job creation, workers' opportunity costs of remaining employed in the state sector are low.

Figure 9a. Optimal paths of the state sector employment under different business climates

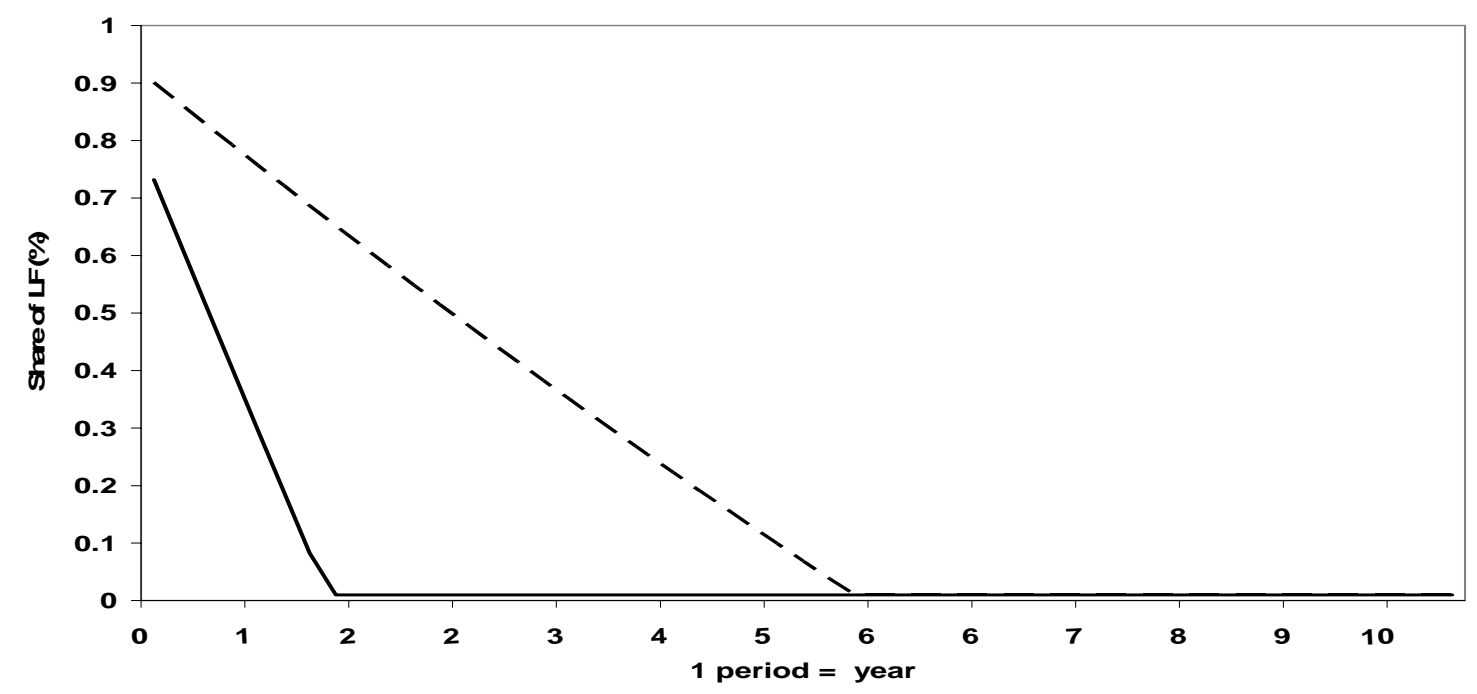


Figure 9b. Optimal paths of unemployment under different quality of business climate

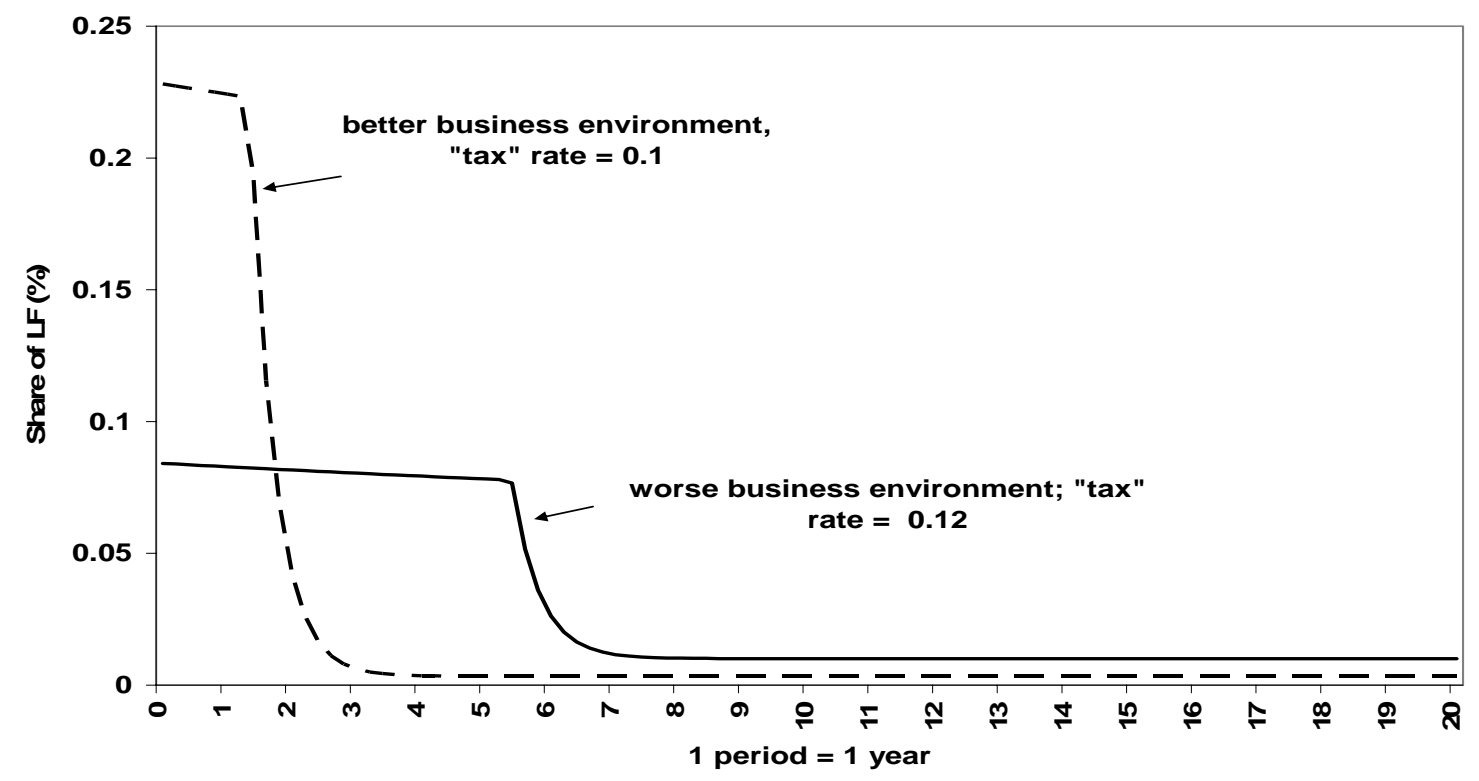

\section{$6 \quad$ Conclusions}

This paper examined differences in private sector, productivity and employment growth in the Central and Eastern European countries and the Baltic (CEEB) versus the non-oil CIS countries, using a model of labor reallocation and firm creation with transaction costs. The CEEB's faster implementation of market reforms and a more enabling institutional set up and business climate stimulated an earlier structural shift towards more productive private firms. This also led to more rapid employment and labor productivity growth, and, consequently, to faster convergence to the income levels of more advanced economies.

All transition countries would benefit from reducing further the remaining obstacles to private sector activities, such as credit constraints, high payroll taxes, and in the new EU members also the persistent skill shortages. The global financial crisis and tightened credit conditions have underscored the importance of improving the efficiency of financial markets, and especially access of small and medium enterprises to credit.

Rational policy makers will and have paced the reduction of public sector employment in line with improvements of the business climate and realistic possibilities of creating private sector jobs, as shown in our analysis. Where such improvements are slow and costly (as, for example, in Belarus due to the political constraints), it is rational to keep workers in public jobs for longer, rather than pursuing radical closure of public enterprises. This said, the resulting slower paths of labor productivity and output growth are inferior to outcomes in an environment with early and vigorous improvements of the business climate. This confirms the importance of undertaking structural reforms and strengthening the business climate early on. These lessons of transition can be applied to other regions and countries where the business climate is still weak and the public sector accounts for a substantial share of employment. 


\section{ANNEX I. Country examples - Contrasting experiences of Estonia and Belarus}

The sections below elaborate on the stylized facts by illustrating the particularly contrasting strategies to market reforms and outcomes in Estonia and Belarus.

Estonia established very swiftly liberal trade regime and business environment after regaining independence in the early 1990s. For some time now, the country has been considered to have one of the most open and competitive economies in the world (OECD, 2009). To some extent, the enabling business environment reflected close proximity to the EU markets and strong incentives of the EU accession that country benefited from. ${ }^{20}$ As Gylfason and Hochreiter (2009) write, for Estonia "...the prospect of rapid EU integration, the EU perspective, provided a critical anchor for sustained political, institutional, and economic reforms across the political spectrum.”

In contrast, with its gradual and often inconsistent approach, Belarus has been lagging behind all other transition economies, perhaps with the exception of Turkmenistan, in terms of the speed of adopting market reforms. In fact, Belarus' business environment is considered to be one of the harshest in the world, with frequent changes of the rules increasing uncertainty surrounding entrepreneurial operations (Smallbone, Slonimski and Pobol, 2008). At the same time, the country has put a great emphasis on maintaining high employment and social stability.

Regarding specific outcomes, Estonia's friendly business environment has led to high rates of firm creation and the rapid private sector take-off (Figure 1, AI), even relative to other new EU member countries undergoing similar transition such as the Czech Republic (Jurajda and Terell, 2008). In fact, the private sector has dominated the economy since mid-1990s; specifically it reached 70 percent of output by 1996 (EBRD, 2005). In Belarus, however, the private sector is in early stages of development, accounting for only about 30 percent of GDP. ${ }^{21}$

While relatively high unemployment rate accompanied a substantial part of the Estonia's transition to the market, the official unemployment rate in Belarus has remained in very low single digits. Specifically, in 2007 the share of the private sector in employment amounted to 76 percent in Estonia. While the 2007 figure is not available for Belarus, the private sector accounted for only about 20 percent of total employment in 1999 way below of 70 percent share in Estonia at that time (EBRD, 2008). However, Belarus' seemingly good labor market performance reflected in low unemployment has been, largely, due to postponed reforms (Brixiova and Volchok, 2005). ${ }^{22}$ Moreover, the average labor productivity grew more rapidly in Estonia than in Belarus (Figure 2, AI). ${ }^{23}$ The productivity gap can be partly explained by markedly higher share of employment in services in Estonia than in Belarus, while Belarus is characterized by a relatively high share of employment in agriculture.

\footnotetext{
${ }^{20}$ Wanchek (2009) found that international trade played a significant role in the emergence of institutions, as the high search cost for foreign buyers reduce the potential to export value-added, or complex, products.

${ }^{21}$ In practice, this number includes large and medium-sized joint stock enterprises with majority of state ownership, so the actual share of the private sector in output may be even lower. Nevertheless, even in the difficult conditions, some innovative, knowledge-based private firms emerged (Smallbone at el., 2008).

${ }^{22}$ A high share of the working age population outside of the labor force in Belarus is another factor.

${ }^{23}$ The result is derived even with the official GDP data, which have likely overstated the actual output in Belarus due to source data that may have introduced an upward bias into the measured GDP (IMF, 2005).
} 
Figure 1, Al. Estonia and Belarus: Shares of the state sector in GDP, 1991 - 2008

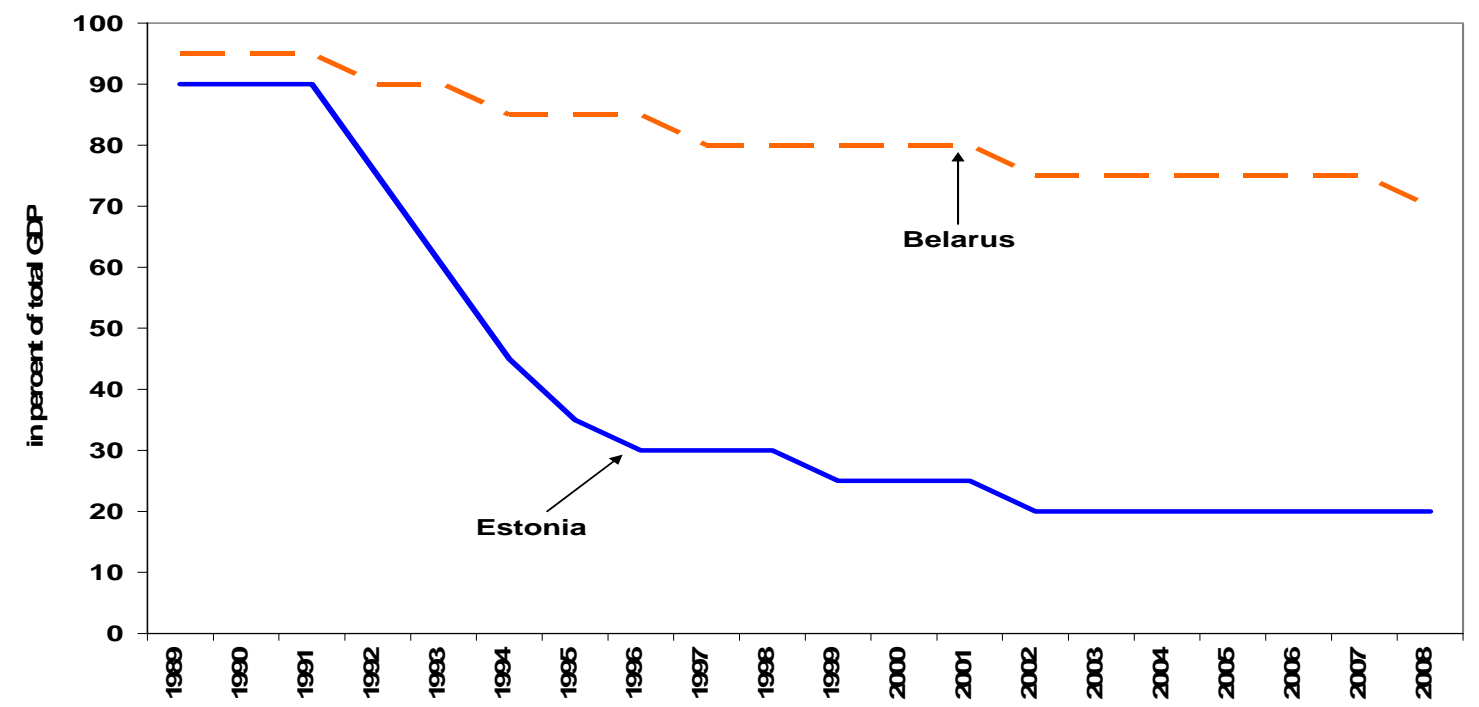

Source: EBRD.

Figure 2, Al. Estonia and Belarus: Average labor productivity indices, $1991-20071$ /

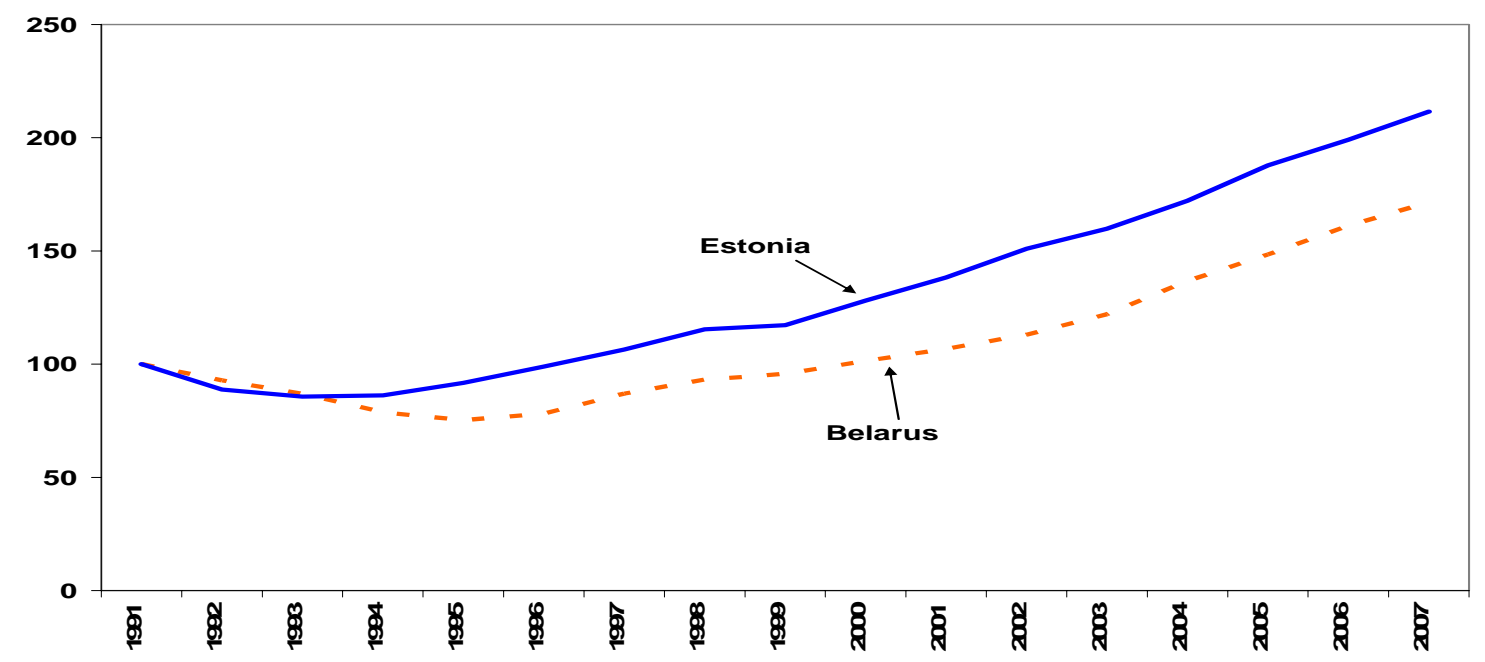

1/ Measured in terms of total employment. Source: EBRD database. 


\section{References}

Aghion, Phillipe and Blanchard, Olivier J. (1994), On the Speed of Transition in Central Europe, S. Fischer and J. Rotemberg (eds.) NBER Macroeconomic Annual 1994, The MIT Press, 283 320.

Aidis, R. (2004), Entrepreneurship and Economic Transition, Tinbergen Institute Discussion PaperNo. 2003-015/2

Aidis, R.; Estrin, S., and Mickiewicz, T. (2009), Entrepreneurial Entry: Which Institutions Matter? IZA Discussion Paper No. 4123.

Arrunada, B. (2007), Pitfalls to Avoid when Measuring Institutions: Is Doing Business DamagingBusiness? Journal of Comparative Economics, Vol. 35, 729 - 747.

Aslund, A. and Johnson, S. (2004), Small Enterprises and Economic Policy, Carnegie Paper No. 43 (Washington D.C.: Carnegie Endowment for International Peace).

Atkenson, A. and Kehoe, P. (1996), Social Insurance and Transition, International Economic Review, Vol. 37, 337 - 402.

Bajona, C. and Locay, L. (2009), Entrepreneurship and Productivity: The Slow Growth of thePlanned Economies, Review of Economic Dynamics, Vol. 12, 505 - 522.

Bastos, F. and Nasir, J. (2004), Productivity and the Investment Climate: What Matters Most?, World Bank Policy Research Working Paper, No. 3335.

Berkowitz, D. and DeJong D. N. (2005), Entrepreneurship and Post-socialist Growth, Oxford Bulletin of Economics and Statistics, Vol. 67 (1), 25 - 46.

Bilsen, V. and Konings, J. (1998), Job Creation, Job Destruction, and Growth of Newly Established Private Firms in Transition Economies: Survey Evidence from Bulgaria, Hungary, and Romania, Journal of Comparative Economics, 26(3), 429-445.

Brixiova, Z. and Volchok, V. (2005), Labor Markets in Belarus, Problems of Economic Transition, Vol. 48 (1), 56 - 67.

Brixiova, Z. and Kiyotaki, N. (1997), Private Sector Development in Transition Economies, Carnegie-Rochester Conference Series on Public Policy, Vol. 46, 241-280.

Burda, M., 1993, Unemployment, Labor Markets and Structural Change in Eastern Europe, Economic Policy, Vol. 8, No. 16, 102-137.

Castanheira, M. and Roland, G. (2000), The Optimal Speed of Transition: A General Equilibrium Analysis, International Economic Review, Vol. 41 (1), 219-239.

De Loecker, J. and Konings, J. (2006), Job reallocation and productivity growth in a post-socialist economy: Evidence from Slovenian manufacturing, European Journal of Political Economy, Vol. 22, 388-408. 
European Bank for Reconstruction and Development (2008), Transition Report: Growth in Transition (London: EBRD).

European Bank for Reconstruction and Development (2005), Transition Report: Business in Transition (London: EBRD).

Faggio, G. and Konings, J. (2003), Job Creation, Job Destruction, and Employment Growth in Transition Economies in the 1990s, Economic Systems (27), 129 - 154.

Fonseca, R., Lopez-Garcia, P. and Pissarides, C. A. (2001), Entrepreneurship, Start-up Costs and Employment, European Economic Review, Vol. 45, 692 - 705.

Gollin, D. (2008), Nobody's Business but My Own: Self-employment and Small Enterprise in Economic Development, Journal of Monetary Economics, Vol. 55, 219-233.

Gylfason, T. and Hochreiter, E. (2009), Growing Apart? A Tale of Two republics: Estonia and Georgia, European Journal of Political Economy, Vol. 25 (3), 355 - 370.

Hopenhayn, H. and Rogerson, R. (1992), Job Turnover and Policy Evaluation: General Equilibrium Analysis, Journal of Political Economy, Vol. 101, 915 - 938.

International Monetary Fund (2005), Belarus: Selected Issues, IMF Country Report No. 05/217, IMF: Washington, DC.

Johnson, S. and Loveman, G. (1995), Starting over in Eastern Europe: Entrepreneurship and Economic Renewal (Boston, Massachusetts: Harvard Business School Press).

Jovanovich, B (1982), Selection and Evolution of the Industry, Econometrica, Vol. 50, 649 - 670.

Jurajda, S. and Terrell, K. (2008), Job Reallocation in Two Cases of Massive Adjustment in Eastern Europe, World Development, Vol. 36(11), 2144-2169

Klapper, L.; Laeven, L. and Rajan, R. (2006), Entry Regulation as a Barrier to Entrepreneurship, Journal of Financial Economics, 82, 591-629.

McMillan, J. and Woodruff, M., C. (2002), The Central Role of Entrepreneurs in TransitionEconomies, Journal of Economic Perspectives, Vol.16, Number 3 (Summer), 153-170.

Mitra, P.; Muravyev, A. and Schaffer, M. (2009), Convergence in Institutions and Market

Outcomes: Cross-country and Time-series Evidence from the Business Environment and Enterprise Performance Surveys in Transition Economies, World Bank Policy Research Working Paper, No. 4819.

Organization for Economic Cooperation and Development (2009), OECD Country Economic Survey - Estonia, OECD, Paris.

Parente, S. L. and Prescott, E. C. (2000), Barriers to Riches (Cambridge: MIT Press).

Rodrik, D. (2008), The Real Exchange Rate and Economic Growth: Theory and Evidence, draft, John F. Kennedy School of Government, Harvard University. 
Roland, G. (2000), Transition and Economics: Politics, Markets, and Firms (Cambridge: MIT Press).

Roland, G. (2004), Understanding Institutional Change: Fast Moving and Slow Moving Institutions, Studies in Comparative International Development, Vol. 38, 109 - 131.

Rutkowski, J. and others (2005), Enhancing Job Opportunities: Eastern Europe and the Former Soviet Union, (Washington, DC: World Bank).

Smallbone, D., Slonimski, A. and Pobol, A. (2008), Struggling to Survive: A Case of a New Technology-Based Enterprise in Belarus, in R. Aidis and F. Welter (editors), Innovation and Entrepreneurship: Successful Start-ups and Businesses in Emerging Economies, Edward Elgar Publishing Limited: Massachusetts.

Smallbone, D. and Venessar, U. (2004), The State of Small and Medium-Sized Enterprises in Estonia on the Way to Accession.

Svejnar, Jan (2001), Transition Economies: Performance and Challenges, William Davidson Institute Working Paper No. 415.

Temple, J. (2005), Dual Economy Models: A Primer for Growth Economists, The Manchester School, Vo. 73, No. 4, pp. 435 - 478.

Tichit, A. (2006), The Optimal Speed of Transition Revisited, European Journal of Political Economy, Vol. 22, 349 - 369.

van Ours, J. (2007), “Compulsion in active labour market programs”, National Institute Economic Review, No. 202, October, 67 - 78.

Wanchek, T. (2009), Exports and Legal Institutions: Exploring the Connection in Transition Economies, Journal of Institutional Economics, Vol. 5 (1), 89-115. 


\section{DAVIDSON INSTITUTE WORKING PAPER SERIES - Most Recent Papers}

The entire Working Paper Series may be downloaded free of charge at: www.wdi.umich.edu

CURRENT AS OF 2/18/10

\begin{tabular}{|c|c|c|}
\hline Publication & Authors & Date \\
\hline $\begin{array}{l}\text { No. 975: MODELING INSTITUTIONS, START-UPS AND PRODUCTIVITY DURING } \\
\text { TRANSITION }\end{array}$ & $\begin{array}{l}\text { Zuzana Brixiová and } \\
\text { Balázs Égert }\end{array}$ & Feb 2010 \\
\hline $\begin{array}{l}\text { No. 974: Pegging the future West African single currency in regard to } \\
\text { internal/external competitiveness: a counterfactual analysis }\end{array}$ & $\begin{array}{l}\text { Gilles Dufrénot and } \\
\text { Kimiko Sugimoto }\end{array}$ & Dec 2009 \\
\hline $\begin{array}{l}\text { No. 973: Unemployment and finance: how do financial and labour market } \\
\text { factors interact? }\end{array}$ & $\begin{array}{c}\text { Donatella Gatti, Christophe } \\
\text { Rault \& Anne-Gaël } \\
\text { Vaubourg } \\
\end{array}$ & $\begin{array}{c}\text { January } \\
2010\end{array}$ \\
\hline No. 972: Identifying Social Entrepreneurs Serving the Poor at the BoP & Abraham M. George & $\begin{array}{l}\text { December } \\
2009\end{array}$ \\
\hline $\begin{array}{l}\text { No. 971: Inflation dynamics and the New Keynesian Phillips curve in the } \\
\text { EU-4 }\end{array}$ & Bořek Vašíček & $\begin{array}{l}\text { October } \\
2009\end{array}$ \\
\hline $\begin{array}{l}\text { No. 970: International Financial Integration And Real Exchange Rate } \\
\text { Long-Run Dynamics In Emerging Countries: Some Panel Evidence }\end{array}$ & $\begin{array}{l}\text { Guglielmo Maria CAPORALE, } \\
\text { Thouraya HADJ AMOR } \\
\text { and Christophe RAULT }\end{array}$ & Sept 2009 \\
\hline $\begin{array}{l}\text { No. 969: Once Bitten, Twice Shy: Experiences Of A Banking Crisis } \\
\text { And Expectations Of Future Crises }\end{array}$ & Shannon Mudd \& Neven Valev & Sept 2009 \\
\hline $\begin{array}{l}\text { No. 968: Monetary policy rules and inflation process in open emerging } \\
\text { economies: evidence for } 12 \text { new EU members }\end{array}$ & Bořek Vašíček & Sept 2009 \\
\hline $\begin{array}{l}\text { No. 967: Extending Likages Between Organizational Analysis And Social } \\
\text { Structure: A Case Study Of The Celebrity-Construction Of A Chinese } \\
\text { Marketplace }\end{array}$ & Mark Jacobs & Aug 2009 \\
\hline $\begin{array}{l}\text { No. 966: Chinese state's economic cooperation related investment: An } \\
\text { investigation of its direction and some implications for outward } \\
\text { investment }\end{array}$ & $\begin{array}{l}\text { Sumon Bhaumik and } \\
\text { Catherine Yap Co }\end{array}$ & Aug 2009 \\
\hline $\begin{array}{l}\text { No. 965: Capital inflows, household debt and the boom-bust cycle in } \\
\text { Estonia }\end{array}$ & $\begin{array}{l}\text { Zuzana Brixiova, Laura Vartia } \\
\text { and Andreas Worgotter }\end{array}$ & July 2009 \\
\hline No. 964: Labour Market Felxibility in Estonia: What More Can be Done? & Zuzana Brixiova & July 2009 \\
\hline $\begin{array}{l}\text { No. 963: Market Globalization by Firms from Emerging Markets \& Small } \\
\text { Countries: An Application of the Neoclassical Trade Model }\end{array}$ & Tamir Agmon & July 2009 \\
\hline $\begin{array}{l}\text { No. 962: Central Bank Communication and Exchange Rate Volatility: A } \\
\text { GARCH Analysis }\end{array}$ & $\begin{array}{l}\text { Roman Horvath and Radovan } \\
\text { Fiser }\end{array}$ & July 2009 \\
\hline $\begin{array}{l}\text { No. 961: On the influence of oil prices on stock markets: } \\
\text { Evidence from panel analysis in GCC countries. }\end{array}$ & $\begin{array}{l}\text { Christophe Rault and Mohamed } \\
\text { El Hedi Arouri }\end{array}$ & June 2009 \\
\hline $\begin{array}{l}\text { No. 960: Oil Prices \& Stock Markets: What Drives What in the Gulf } \\
\text { Corporation Council Countries? }\end{array}$ & $\begin{array}{l}\text { Christophe Rault and Mohamed } \\
\text { El Hedi Arouri }\end{array}$ & June 2009 \\
\hline $\begin{array}{l}\text { No. 959: Trade Specialisation And Economic Convergence: } \\
\text { Evidence From Two Eastern European Countries }\end{array}$ & $\begin{array}{l}\text { Christophe Rault, Guglielmo } \\
\text { Caporale, Robert Sova \& } \\
\text { Anamaria Sova }\end{array}$ & June 2009 \\
\hline $\begin{array}{l}\text { No. 958: Inflation differentials in the Euro area and their determinants } \\
\text { - an empirical view }\end{array}$ & $\begin{array}{c}\text { Juan Ignacio Aldasoro \& Václav } \\
\text { Žd'árek }\end{array}$ & April 2009 \\
\hline No. 957: Infrastructure and growth: Empirical evidence & $\begin{array}{c}\text { Balazs Egert, Tomasz } \\
\text { Kozluk and Douglas Sutherland }\end{array}$ & April 2009 \\
\hline $\begin{array}{l}\text { No. 956: Infrastructure investment in network industries: The role of } \\
\text { incentive regulation and regulatory independence }\end{array}$ & Balazs Egert & April 2009 \\
\hline $\begin{array}{l}\text { No. 955: The impact of monetary and commodity fundamentals, macro } \\
\text { news and central bank communication on the exchange rate: } \\
\text { Evidence from South Africa }\end{array}$ & Balazs Egert & April 2009 \\
\hline $\begin{array}{l}\text { No. 954: "Family" ownership, tunneling and earnings management: } \\
\text { A review of the literature }\end{array}$ & $\begin{array}{l}\text { Sumon Bhaumik an } \\
\text { Gregoriou }\end{array}$ & $\begin{array}{l}\text { March } \\
2009\end{array}$ \\
\hline
\end{tabular}

